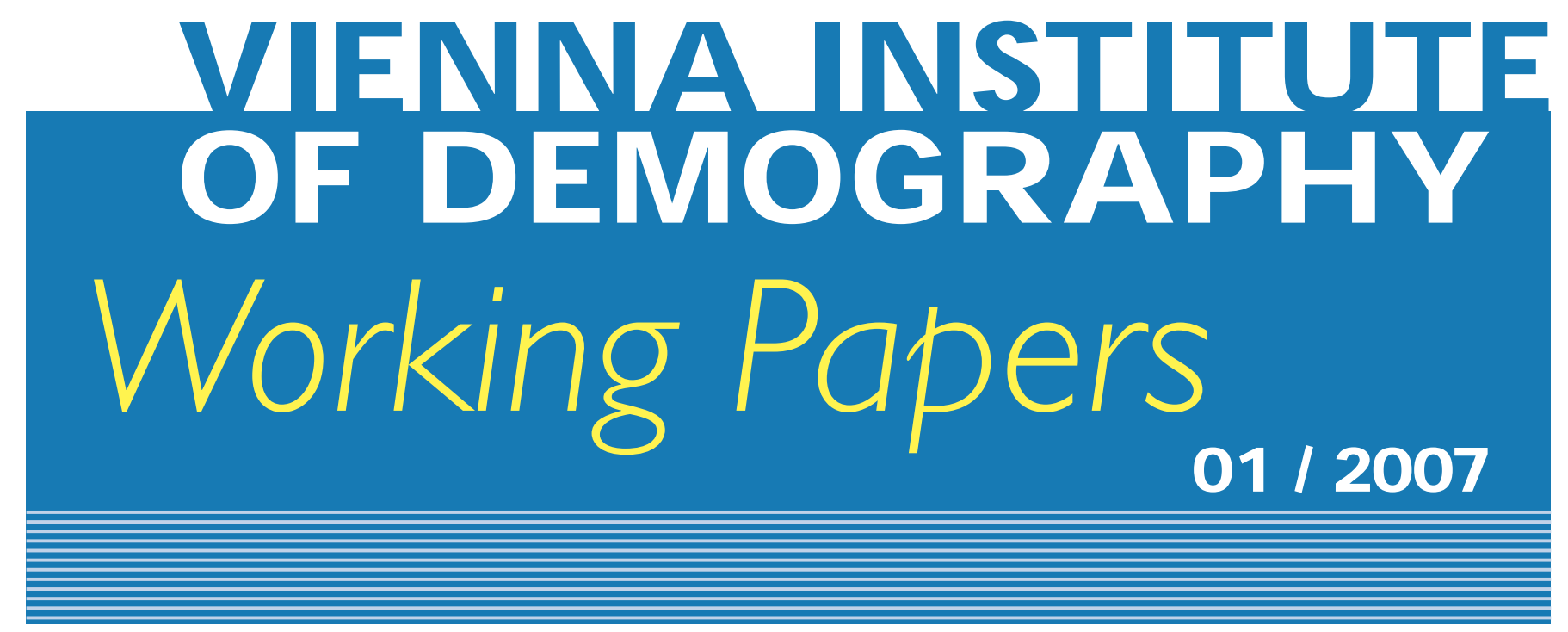

M aria W inkler-Dworak and Laurent Toulemon

\title{
Gender Differences in the Transition to Adulthood in France: Is There Convergence $\mathbf{O}$ ver the Recent Period?
}

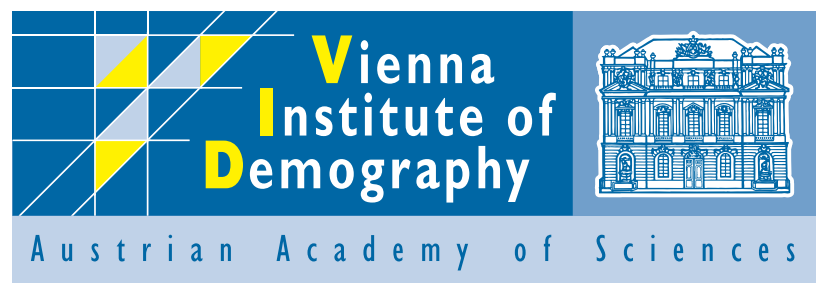

Vienna Institute of D emography

A ustrian A cademy of Sciences

Prinz Eugen-Straße 8-10 · A-1040 Vienna · A ustria

E-Mail: vid@ oeaw.ac.at

W ebsite: www.oeaw.ac.at/vid 


\begin{abstract}
Numerous studies have shown that educational attainment and labour force status have a strong impact on the timing of family formation for both men and women. The effects of educational level, enrolment in an educational setting and employment seem to be different for men and women. The aim of this paper is to investigate how gender-specific differences in family formation changed over time, particularly, whether these differences have vanished in recent years. We use a large-scale survey (more than 240,000 men and women born after 1940) conducted within the French 1999 census and apply event history techniques. The sample size allows us to test our hypotheses with more sophisticated models that cover several interactions. Our data fully support the convergence hypothesis for men and women with regard to the effects caused by educational attainment and the working status (working/not working). However, it is only partly relevant for the effects of their enrolment status on entry into first union and parenthood. The impact of work experience on first union and first parenthood has developed similarly over time for both men and women.
\end{abstract}

\title{
Keywords
}

Transition to adulthood, family formation, event history analysis, France, gender, education

\section{Authors}

Maria Winkler-Dworak is a Research Scholar at the Vienna Institute of Demography of the Austrian Academy of Sciences.

Laurent Toulemon is a Research Scholar at the Institut National d'Etudes Démographiques, Paris.

\section{Acknowledgements}

A large part of this work was undertaken while Maria Winkler-Dworak visited the Institut National d'Etudes Démographiques. Her work was subsidised by a grant (contract HPRNCT-2001-00234) offered in the framework of the European Community's Human Potential Programme. 


\title{
Gender Differences in the Transition to Adulthood in France: Is There Convergence Over the Recent Period?
}

\author{
Maria Winkler-Dworak and Laurent Toulemon
}

\section{Introduction}

Educational attainment and employment were shown to be the main predictors of the timing of family formation for males and females, both in theoretical reasoning (Becker 1981; Oppenheimer 1988) and on an empirical basis (Goldscheider and Waite 1986; Hoem 1986; Blossfeld and Huinik 1991; Thornton et al. 1995; Liefbroer and Corijn 1999). However, these studies show differences between men and women regarding the impact of educational level, enrolment in school and employment. For instance, based on the New Home Economics theory, family formation rates are expected to increase with rising levels of education for men but to decrease for women (Becker 1981), since higher education is associated with higher expected earning levels. While the latter increase men's attractiveness on the marriage market, they imply higher opportunity costs of housework and child rearing and greater economic independence for women (Becker 1981). Hence according to New Home Economics, the higher the educational levels of women and the better their career prospects, the more they will try to postpone or even avoid marriage and motherhood (Blossfeld and Huinink 1991).

Apart from the influence of educational attainment on the timing of family formation, longer enrolment in school as such also has a delaying effect (Blossfeld and Huinink 1991; Blossfeld 1995). Goldscheider and Waite (1986) and Coppola (2004) found that the negative effect of school enrolment is greater for women than for men, which seems to imply that staying in education while being married is usually more difficult for women than for men (Goldscheider and Waite 1986).

The employment status is crucial for a person's ability to form a union and to become a parent, particularly for men. Hence, difficulties with finding a job hinder men to start a family (Goldscheider and Waite 1986; Oppenheimer et al. 1997; Liefbroer and Corijn 1999). However, for women, being unemployed does not necessarily delay their entering into a union and motherhood (Liefbroer and Corijn 1999; Blossfeld and Huinink 1991, Meron and Widmer 2002).

Educational attainment and employment of males and females underwent tremendous changes in the past few decades. In fact, education levels have risen for both sexes, but more dramatically for women, "so that [in France] at university, girls are now more numerous than boys" (Leridon and Toulemon 1995). The educational expansion was accompanied by a rise in female employment. Leridon and Toulemon (1995) report that the rate of employment for women aged 25 to 39 years - where the "competition between maternity and economic occupation is crucial"- almost doubled from 41.5 per cent to 74 per cent between 1962 and 1989. In 2002, the labour force participation rate of women aged 25 to 34 was as high as 79 per cent (ILO 2003). 
In most western countries, the pattern of family formation has also been subject to dramatic changes since the 1960s. France may serve as an example. In this country, the mean age at first marriage rose rapidly from about 22 years in the early 1970s to about 28 years in 2000. Similarly, the mean age at first birth increased from 24 years in 1970 to about 28 years in 2000 (Council of Europe 2005). Furthermore, the period measure of the proportion of women ever-marrying fell from 0.90 in 1970 to 0.65 in 1995 (Goldstein 2002, Beaumel et al. 2006). Moreover, since the late-1960s, the number of consensual unions has risen dramatically: in 1995, about 90 per cent of all first unions began outside marriage (Toulemon 1997). During the same time-span, the proportion of extra-marital births increased from about 7 per cent in 1970 to about 43 per cent in 2000 (Council of Europe 2005).

The spread of cohabitation may also have changed gender differences in union formation, as Leridon and Toulemon (1995) found that, in France, "cohabitation is more strongly associated with new — less sex-differentiated - roles, whilst married couples adhere to a more traditional pattern.” Liefbroer and Corijn (1999) argue that the changing pattern of the transition to adulthood has altered the social meaning of marriage, so that the "date of marriage may increasingly represent the time, when it is most convenient [...], rather than signifying the date that a socially meaningful commitment occurred" (Oppenheimer 1994). Moreover, parenthood entails more commitment than union formation and is irreversible (Liefbroer and Corijn 1999). Hence, Liefbroer and Corijn see a hierarchy in the impact of educational attainment and employment on women's family formation, where the negative impact is smaller for first unions and stronger for entry into motherhood. This may imply smaller gender differences in the entry into a first union, but more pronounced differences between men and women for the transition to parenthood.

The focus of this paper is on investigating the differences between men and women in France in their transition to adulthood and to analyse how these differences changed. Did the overall differences diminish over time? Did the social differences between men and between women become more similar?

We studied the question of convergence by applying event history techniques, which model the entry into first union and first parenthood, respectively. We used hazard regression to analyse the different impact of educational attainment and employment on males and females and to find out how these differences have changed over time, and in particular, whether they have vanished in recent periods.

Section 2 of the paper contains a detailed discussion of family formation theories in relation to education and employment and their empirical relevance. Section 3 introduces the data and methods, and section 4 presents the results. Section 5 contains the conclusions and outlines areas for further analysis.

\section{Theoretical Framework and Hypotheses}

There are several theories about why people marry and what factors influence the timing of marriage. In the New Home Economics theory, marriage is seen as a rational choice made 
by individuals for whom the gains from marriage outweigh the benefits of remaining single. Given the complementarity of men and women in the household production of commodities, these individuals would be more productive in a joint than in a single household. If each sex specialises in its comparative advantage ${ }^{1}$, the gendered division of labour within households will creates gains from marriage (Becker 1976, 1981). Gains from marriage thus are based on the assumption of complementarity between men and women and on their market opportunities.

On the one hand, higher wages imply a higher total income of the joint household, which increases the gain from marriage (income effect). On the other hand, higher wages reduce the comparative advantage of the household sector, which, in turn, increases the opportunity costs of household work (price effect). Hence, the gender-specific division of labour within the family becomes less advantageous for the individual specialising in household tasks, which reduces the gains from marriage. If a traditional division of labour prevails, the income effect is expected to dominate among men, whereas the price effect is supposed to outweigh the income effect among women (Liefbroer and Corijn 1999). As higher educational attainment is associated with higher expected earning levels (which implies higher economic independence), Becker's theory predicts a positive impact of education for males and a negative one for females.

However, Becker's specialisation model has been heavily criticised for several reasons. In particular Oppenheimer (2000) argues that "sex role specialisation is essentially a high risk and inflexible family strategy in an independent nuclear family system." Thus, highly educated women with a greater labour market potential are more attractive to their future spouses than less educated women with poor employment prospects.

Moreover, Liefbroer and Corijn (1999) found that the impact of educational attainment and labour force participation depends on the degree of incompatibility between employment and family life. Using Dutch and Flemish survey data, they empirically verified their 'societal contingency hypothesis' that the more gender "equality is a dominant cultural value and the better structural opportunities to combine work and family life, the weaker the impact of educational attainment and labour force participation." Moreover, Liefbroer and Corijn (1999, p. 50) argue that in "the past, the lack of efficient contraceptives resulted in a very close connection between [marriage and parenthood]. Either initialisation of sexual intercourse at marriage led to pregnancy soon after the wedding, or the initialisation of sexual intercourse before marriage led to a 'forced' marriage soon after the women became pregnant. As a result, women who preferred to postpone childbearing were well-advised to postpone marriage as well.” However, in many countries, the incompatibility of female labour force participation and family life weakened in the second half of the $20^{\text {th }}$ century (Gauthier 1996), and with the provision of efficient

\footnotetext{
${ }^{1}$ A household member is said to have a comparative advantage in the household if the ratio of the marginal product in the household to his/her wage rate on the market is higher for him/her than for the other household member(s) if all contribute the same amount of time to the household and all invest in the same human capital (Becker 1981).
} 
contraceptives, the link between first union and the occurrence of a first child was broken ${ }^{2}$, which, in turn, may have reduced the negative impact of educational attainment on first union.

In addition, Thornton, Axinn, and Teachman (1995) suggest that the opportunity costs of cohabitation are lower than those of marriage. Similarly, Oppenheimer (1988) argues that the low opportunity costs of unmarried cohabitation make this living arrangement especially attractive for better-educated women. From a bargaining theory perspective, Cherlin (2000) found that women incorporate premarital cohabitation into their search processes because cohabitation provides a better opportunity to observe men's earnings potential and willingness to share household and child-raising tasks.

The theoretical considerations outlined above lead to the formulation of our first hypothesis.

Hypothesis 1: The effect of the educational level attained is positive for men, but negative or U-shaped for women. However, with spreading cohabitation and the creation of institutions that facilitate the reconciliation of family life and work, the negative link between family formation and educational level has weakened over time. Moreover, in recent periods, union formation rates for low-educated women are declining, which implies that the educational level has a less decreasing or even an increasing impact on union formation rates.

Huinik (1995) finds that males' chances to get married actually increase with earning levels. Goldscheider and Waite (1986) note a positive effect of men's education on marriage rates, albeit only before age 25, while Brüderl and Diekmann (1994) report that the effect of men's educational attainment changed from positive to negative across cohorts.

Empirical evidence of the impact of education on women's family formation is mixed. Some studies indicate positive effects of female education on marriage (Goldscheider and Waite 1986) while others record insignificant effects (Blossfeld and Huinik 1991; Hoem 1986) and yet others note negative effects (Preston and Richards 1975). Furthermore, for French women, Leridon and Toulemon (1995) identified a positive effect of education on cohabitation intensities but a negative effect on marriage intensities.

Empirical evidence regarding the transition to first parenthood is also mixed. Liefbroer and Corijn (1999) found a negative impact of educational attainment on first conception intensities for Dutch and Flemish females, while Buber (2002) reported a Ushaped effect of the educational level on the rate of having a first child for Austrian women. Blossfeld and Huinink (1991) identified a positive effect of the educational level on the entry into first motherhood, which they attribute to the increasing pressure exercised not only by "the potential increase of medical problems with lateness of first births, but

\footnotetext{
${ }^{2}$ Robert-Bobée and Mazuy (2003) show that, in France, the average duration between union formation and the arrival of the first child is increasing over birth cohorts from about two years for women born before 1940 and men born before 1935 to about 3.5 years for men and women born in the early 1960s.
} 
[by] societal age norms as well” (Blossfeld and Huinink 1991), since acquiring higher education takes time and is connected with a higher school-leaving age of women.

Moreover, the prolonged period of education implied by higher educational levels has a substantial impact on the timing of union formation. In particular when attending school or university, students are normally not economically independent and heavily rely on their parents' financial support (Blossfeld and Huinik 1991; Blossfeld and Jaenichen 1992; Coppola 2004). In addition, Blossfeld and Huinik (1991, p. 158) state that "from a sociological point of view, there exist normative expectations in the society that young people who attend school are not 'at risk' of entering marriage." The incompatibility of being a student and engaging in adult family activities thus delays family formation until the educational career has been completed.

However, as cohabitation generally involves a lower commitment than marriage, its opportunity costs may be lower than those of marriage (Oppenheimer 1988). Therefore, cohabitation and being a student may be less conflicting and "students may be more willing to enter cohabitation than marriage” (Thornton et al. 1995).

Hence, we wanted to test the following hypothesis:

Hypothesis 2: The effect of educational enrolment is negative for both sexes but stronger for women than for men. However, in recent periods, it weakened for union formation and strengthened for first parenthood for both men and women. Since the completion of education is a foreseeable event, the negative impact of educational enrolment on union formation is significantly lower shortly before a student leaves school or university.

There exists overwhelming empirical evidence that being in education has a strong negative impact on entry into first union (e.g., Hoem 1986; Blossfeld and Huinik 1991; Blossfeld and Jaenichen 1992; Leridon and Toulemon 1995; Coppola 2004) and on first parenthood (e.g., Blossfeld and Huinink 1991; Blossfeld and Jaenichen 1992; Buber 2002). However, several studies show gender differences in the impact of educational enrolment on union formation. In particular, they find that the effect of school enrolment is stronger for women than for men (Goldscheider and Waite 1986; Blossfeld and Huinik 1991; Coppola 2004), which seems to imply that remaining in an educational setting while being married is usually more difficult for women than for men (Goldscheider and Waite 1986). However, when examining recent French data, Robert-Bobée and Mazuy (2003) found that women form a union while being in education more often than men do, because they enter their first union at a lower age and complete their studies later than men.

Finishing education is one of the markers in the transition to adulthood; entry into employment is another. An individual's current labour market position affects his or her ability to form a union because it is a means to achieve the necessary economic independence to set up an own household (Oppenheimer 1988). According to New Home Economics, having an own household speeds up union formation for men, while it makes women avoid union formation (Becker 1976, 1981). However, women might also perceive economic independence as a means to share the costs of setting up a common household, 
which will accelerate the entry into a union (Oppenheimer 1994). Nevertheless, Oppenheimer and Lewin (1999) state that it is still unlikely that "women's familial roles are normatively defined in terms of their ability to make a major and long-term stable income contribution to the family to the same degree as men's." Hence, for both sexes, men's career and career maturity play a more important role than women's with respect to the timing of marriage.

However, the employment status is not the only decisive criterion. Work experience may also affect the timing of family formation. The more work experience a person has, the more stable his/her employment will be. Kravdal (1999) finds that marriage requires a stronger economic underpinning than informal cohabitation. As mentioned earlier, Cherlin (2000) claims that women incorporate premarital cohabitation into their search processes because it provides a better opportunity to observe men's earnings potential. Due to the spread of cohabitation, the effect of work experience on union formation may therefore have decreased in recent periods.

However, the effect of work experience on the rate of having a first child might be rising, since parenthood usually entails more commitment than union formation (Liefbroer and Corijn 1999). These considerations led to our third set of hypotheses.

Hypothesis 3a: The effect of working status on union formation is stronger for men than for women, but the difference was more pronounced in former periods than recently, while it may still persist for fertility behaviours.

Hypothesis $3 b$ : The impact of the time elapsed since taking on the first job is stronger for men than for women, though the difference has decreased in recent periods. Moreover, in the most recent period, it has become weaker for first unions and stronger for first births for both sexes.

Several studies empirically verify that unemployment hampers the start of family formation for men (Goldscheider and Waite 1986; Oppenheimer et al. 1997; Liefbroer and Corijn 1999). In contrast, there is empirical evidence that, for women, being unemployed does not necessarily delay their entry into union (Blossfeld and Huinik 1991; Liefbroer and Corijn 1999) or may even accelerate their entry into motherhood (Buber 2002; Liefbroer and Corijn 1999). However, in some cases, women's economic independence was found to accelerate their entry into union (McLaughlin et al. 1993; Oppenheimer 1994) and into motherhood (Meron and Widmer 2002).

Regarding work experience, Oppenheimer and Lewin (1999) noted that young men's career maturity has a strong positive impact on their marriage formation. Furthermore, Kravdal (1999) obtained that Norwegian single women with less than one year of work experience have significantly lower union formation rates than those who have worked for more than two years. For entry into motherhood, Buber (2002) found that Austrian women avoid becoming pregnant shortly after finishing education. Moreover, Kravdal (1994) showed for Norwegian women that first birth rates sharply increase after about four years of work experience. 


\section{Data and Methods}

The data for this study come from the French Etude de l'Histoire Familiale (EHF) 1999, which was conducted together with the census in March 1999 (Cassan, Héran and Toulemon 2000). 235,000 women and 145,000 completed an additional questionnaire on their children, partnerships, working life, social origin, place of birth and languages spoken in the family. We restricted our sample to birth cohorts after 1940. Immigrants were only included if they had arrived in metropolitan France before they reached age 15, i.e., they underwent their transition to adulthood in France. Moreover, we excluded observations if the event (pregnancy or union formation) took place before the age of 15 . Finally, about 145,000 women and about 95,000 men remained in our sample, of whom about 82 per cent of all women and about 74 per cent of all men entered into a first union. Furthermore, about 70 per cent of all women and 60 per cent of all men entered into first parenthood ${ }^{3}$.

In our study, we followed individuals from their $15^{\text {th }}$ birthday until the time of the event, i.e., union formation or conception of first child. There are no competing events. Furthermore, we censored by 1 January 1999 or by their $40^{\text {th }}$ birthday. Sample weights were used to correct for the higher share of non-responses of certain population groups.

We modelled the intensity of forming a union or conceiving the first child by using a piecewise constant exponential model (Blossfeld and Rohwer 2002). We assumed the effect of age to be constant over single years of age in order to achieve maximum flexibility. Moreover, we controlled for social origin, educational level, enrolment and employment status, and calendar period. For the entry into first union we additionally controlled for pregnancy or the presence of a child, and for parenthood we included union status in the control variables. ${ }^{4}$

\section{Explanatory Variables}

In order to test our hypotheses, we focused on the effects of educational and employment variables, while controlling for individual characteristics and characteristics of the family of origin. Since we were particularly interested in the differences of these effects by gender, we ran separate model regressions for males and females.

With regard to individual characteristics, we first controlled for the effect of age. The process of family formation is supposed to be highly dependent on age, and union formation rates and the rate of conception of a first child usually show a bell-shaped pattern with increasing age (Blossfeld and Huinik 1991; Buber 2002; Coppola 2004). By

\footnotetext{
${ }^{3}$ These percentages were derived by using sample weights in order to correct for the bias related to higher proportions of non-response of certain population groups. The raw percentages are 82 per cent and 78 per cent for all women and men, respectively, entering a first union; and 72 per cent and 60 per cent for all women and men, respectively, who had a first child.

${ }^{4}$ Several authors found that family-building behaviours such as union formation, particularly marriage and conception, are interrelated and estimation procedures not taking into account the possible endogeneity may lead to biased results of the effects they have on each other (see, e.g., Brien et al. 1999 for modelling the interrelations between cohabitation, marriage and non-marital conception).
} 
assuming a piecewise constant exponential model as outlined above, we incorporated age in single-year steps.

For the entry into a first union, we controlled for the presence of pregnancy or a child (time varying covariate). Conception outside a union may accelerate first union formation because the father-to-be is a potential partner for pregnant women and people want to offer the child the social and economic protection of a union (Brien et al. 1999). Moreover, normative pressures may increase the incentive to 'legitimise' the birth (Baizán et al. 2004). Indeed, several studies show a strong positive effect of pregnancy on union formation (Goldscheider and Waite 1986; Blossfeld and Huinink 1997; Brien et al. 1999; Baizán et al. 2004; Toulemon 1997). Since there is a time lag of about one month between conception and the detection of pregnancy, we followed pregnancies from one month after conception.

However, once the child is born, its presence may impose constraints on resources and time, which may hamper union formation (Baizán et al. 2004). In fact, Brien et al. (1999) found that the risk of entering into marriage or cohabitation drops to approximately the level before conception or even below that level for US women. Baizán et al. (2004) obtained similar findings for German and Swedish women, as well as Toulemon (1997) for French women.

When investigating the entry into first parenthood, we also considered the union status, because being in a union is viewed as the appropriate setting for having children and individuals tend to avoid having a birth out of union (Baizan et al. 2004; Toulemon 1995). Moreover, there exists a preference for having the first child in a marriage rather than in a cohabiting union (Baizan et al. 2004). Hence, when controlling for union status in the hazard regression of first conception rates, we distinguished between out of union, consensual union, and marriage.

Apart from individual characteristics we also controlled for characteristics of the family of origin, i.e., the parents' socio-economic position and the number of siblings (both time-constant variables). Indeed, several studies show that family formation is strongly influenced by some characteristics of the family of origin. In particular the parents' socioeconomic position influences the timing of family formation. The effect is not limited to income positions, properties, consumption styles, and economic strategies of families, which create social opportunities for children, but also comprises their social orientations, values, and beliefs, which influence family, educational and career decisions (Blossfeld and Huinik 1991). Therefore, controlling for the socio-professional status of the father is common in analyses of family formation (Goldscheider and Waite 1986; Blossfeld and Huinik 1991; Leridon and Toulemon 1995; Thornton et al. 1995). In particular, we distinguished between farmers, self-employed persons, unskilled workers, skilled workers, low-level white-collar, medium-level white-collar, and high-level white-collar employees. 
We also tried to incorporate the mothers' socio-professional status. However when controlling for the other characteristics, the effects turned out to be minor and mostly insignificant and were, therefore, not included for parsimony considerations. ${ }^{5}$

Moreover, we took into account the number of siblings, because there is empirical evidence that individuals in large households tend to enter a first union and first parenthood earlier (Blossfeld and Huinink 1991; Billari and Philipov 2004). We considered zero, one, two, three, four or five and more siblings.

Our main explanatory variables were educational level, enrolment and working status (all time-varying covariates). Concerning the educational level, we distinguished between primary (including no degree), secondary and tertiary education. Within the secondary level of education, we distinguished further between short secondary studies (Brevet d'Études du Premier Cycle, BEPC, including brevet élémentaire and brevet des colleges), long professional apprenticeship (Certificat d'Aptitude Professionel, CAP), long professional studies (Brevet d'Études Professionels, BEP), and completed secondary studies (Baccalauréat).

In France, schooling between ages 6 and 16 has been compulsory since 1967, and was compulsory from 6 to 14 before 1967. Primary schooling lasts from 6 to 11, and lower secondary education from ages 11 to 15 . At the end of lower secondary education, pupils can take the brevet exam (BEPC and its predecessors, the brevet élémentaire and brevet des collèges). Before compulsory schooling was prolonged, the vast majority of children attended extended primary education comprising eight grades, which led to the Certificat d'Études Primaires (Grenet 2004). In the upper secondary level, children either enter a lycée, which ends with the Baccalauréat, or start a vocational training, which either leads to BEP or CAP (Eurydice 2005).

We do not have the complete educational history, but only the highest degree attained and the respondents' age at the end of studies. When constructing the time-varying educational level we therefore assumed that students reach the BEPC by age 15, the Baccalauréat by age 18, and the first university level by age 21 .

Concerning the enrolment status, we extended the commonly used dichotomous variable by taking into account the number of years after leaving school, since this has been shown to have a significant effect, at least on entry into motherhood (Buber 2002). As the end of studies is a foreseeable event, at least in the final year of enrolment, we distinguished between more than 1 year to finish school and the last year of schooling. Indeed, from a theoretical perspective, Thornton et al. (1995) note that "[f]or young people who decide to combine marriage and student roles, marrying near the end of one's schooling minimises the time spent in conflicting roles.” Therefore, we distinguished between enrolled and more than one year before finishing education, being in the final year of education, and first, second, third and more than three years after leaving school.

\footnotetext{
${ }^{5}$ The Bayesian Information Criteria improved, when we left out the mothers' socio-professional status.
} 
Our third main explanatory variable was employment status, i.e., working versus not working. In order to incorporate the pace and difficulties on the way towards a stable work career, we took into account the time that had elapsed since the person started his/her first job in the employment status. Hence, we distinguished between not working, and having worked for one, two, three and more than three years.

Finally, our model included the calendar period effects (time-varying covariate) by splitting calendar time into five-year groups. As we only considered birth cohorts born after 1940, there were only few events in the years 1955 to 1960. Therefore, we combined the second half of the 1950s with the first half of the 1960s. Hence, we distinguished between the calendar periods 1955-1964, 1970-1974, 1975-1979, 1980-1984, 19851989, 1990-1994, and 1995-1998.

In order to detect changes in the assumed effects over time, we modelled interactions with the period variable and the other explanatory variables. We employed linear splines with a node at 1975-1979 to lower the number of coefficients that had to be estimated. Taking the calendar period 1975-1979 as a reference category, we estimated the average change of the covariates' effect from 1955-1964 to 1975-1979 and the average change from 1975-1979 to 1995-1998.

The size of the dataset even allowed us to check whether the effects of our main explanatory variables changed for specific groups, i.e., for children of high-level whitecollar workers, individuals with a university degree, etc. Therefore, we first modelled the interactions of the educational and employment variables with the covariates that define the group membership, and then explored how these interactions changed over time.

The models were estimated by maximum likelihood, using the statistical software package STATA (StataCorp 2006). Model selection was based on the Bayesian Information Criteria (BIC), since they also let us to compare non-nested models.

\section{Results}

\subsection{Union Formation}

Table 1 shows the parameter estimates for the entry into a first union for men and women. We controlled for age, number of siblings, father's socio-professional status, pregnancy, level of education, enrolment status, working status, and calendar period (model A). The figures in Table 1 are the estimated values for the coefficients of the regression on the log hazard. In order to derive the relative risk of the specific category, one has to evaluate the exponential function at the estimated coefficient. Figure 1 shows the estimates for the men and women of model A as presented in Table 1.

Most of the covariates display the expected effects. With increasing age, the union formation rates exhibit a bell-shaped pattern for both men and women, with female union intensities reaching their highest values about two years earlier than those for males (age 21 versus age 23). Moreover, while young women display higher union intensities than 
young men, from their mid-twenties onwards, men and women show similar values for the risk of entering into a first union. Previous studies have shown that men enter a union significantly later than women (e.g., Coppola 2004). By estimating the models for males and females separately, we were able to demonstrate that the gender difference is particularly pronounced before age 25, while it is rather small for ages above 25 .

Growing up with at least one sibling also has a positive impact on union formation. This holds true for men and women, though being the only child has a slightly more negative effect on union formation for men than for women. However, the presence of more than one sibling has only a minor and hardly significant effect.

The father's profession has almost no significant impact on men's and women's union formation, except for men whose fathers are farmers. Being a farmer's son reduces union formation intensities by 12 per cent! This may be due to the fact that such men have a higher probability to become farmers themselves as compared to children with another social background. Moreover, chances to get married are lower for farmers than for men in other professions (Courgeau and Lelièvre 1986). Furthermore, men whose fathers are medium or high-level white-collar workers have slightly higher union formation rates (about 4 per cent), while this is not the case for women. On the contrary, being the daughter of a low-level white-collar worker has a significant, slightly negative effect on the girl's union formation (about 3 per cent).

The presence of a pregnancy strongly accelerates union formation. In this case, men and women show 12-fold and 8-fold higher union formation rates than before conception. After the birth of the child, union formation intensities steeply decrease. In fact, the union formation rates for men and women are 76 and 17 per cent, respectively, higher than before conception. The gender difference may be due to the fact that some men, who did not form a union with the mother of their first child, failed to report about this child. In this case, the estimates have an upward bias.

Educational attainment has a significant, positive effect on union formation intensities for men and women. However, low education (primary education only or no degree) has a significant, negative impact on union formation for men, while there is no significant effect for women. Especially low-educated men have about 16 per cent lower union formation rates than those with a BEPC. In contrast, men and women with a CAP degree show about 4 per cent higher union formation intensities than those with a BEPC degree. Furthermore, holding a BEP degree increases the union formation rates for women by about 9 per cent, while there is no significant effect for men. Having the baccalauréat raises the risk of entering into a first union by about 13 per cent, while a university degree increases union formation rates by 54 per cent for both men and women. Summing up, we may thus say that our hypothesis was not confirmed, because we noted an increasing impact of the educational level on union formation rates for both men and women, and therefore, no gender differences, except for the lowest educational level.

Being in education has a significant negative impact on union formation for both men and women, with a lower effect in the final year. According to Thornton et al. (1995) students entering a union in the final year of their education spend less time in conflicting 
roles. However, it may also be the case that the conflict between forming a union and being a student makes many students drop out in an earlier stage of their education, which might cause an upward bias in the estimate of the effect of enrolment shortly before leaving school.

In line with our hypothesis, we found that the effect of enrolment in education is stronger for women than for men. In particular, enrolment decreases union formation rates by 71 and 43 per cent for those women and men, respectively, who still have more than one year until graduation. In the final year of education, union formation rates are by about 27 and 11 per cent lower for female and male students, respectively.

Surprisingly, the effect of the time that elapsed since they left school is negative for women and positive for men. Moreover, the longer the period since graduation, the stronger the negative impact is for the women! In contrast, the time that elapsed since they started their first job has a significant positive impact on union formation. In particular in the second year of employment women exhibit by about nine per cent higher union formation rates as compared to the first year spent at work. In the third year of employment, female union formation intensities grow to a difference of about 21 per cent and further increase to about 31 per cent for three and more years of work experience. Men show similar values, although the rise in union formation rates with increasing working experience is less steep. In contrast, not having work lowers the risk of entering into a first union much more for men than for women (36 versus 16 per cent).

By additionally controlling for the time that has elapsed since the respondent started his/her first job, we thus show that work experience rather than the time elapsed since graduation speeds up union formation. In order to study the relation between the effects of work experience and enrolment status (including the time since graduation) in more depth, we explicitly modelled the interaction between the two explanatory variables in our next step.

Finally, we found a hump-shaped pattern for calendar period effects on union formation for men and women, with rather stable estimated effects since 1985.

As mentioned above, we explicitly modelled the interaction between enrolment and employment status and their effect on union formation. However, if we had incorporated all interactions between the different categories of enrolment and employment status, we would have had to estimate an additional 20 coefficients. Therefore, we combined some interaction categories in a meaningful way, which is also confirmed by the fact that the BIC improved relative to model $\mathrm{A}$ as well as relative to the model including all the interactions (result not shown). In particular, we distinguished between enrolled and more than one year to graduation, final year in school, left school less than three years ago, and left school 3 and more years ago for non-working individuals. For those working, we differentiated between enrolled and more than one year until graduation, final year in school, left school and working $1^{\text {st }}$ year, left school and working $2^{\text {nd }}$ year, left school and working $3^{\text {rd }}$ year, and left school and working three and more years. The estimated parameter values of the resulting model (i.e., model B) are presented in Table 1. 
We found that being enrolled significantly decreases the union formation rates for working and non-working individuals. In particular if they still have more than one year until graduation, the risk of entering into a first union decreases by about 77 per cent for non-working women and by 65 per cent for non-working men as compared to those who just finished school and entered employment. In contrast, working students have by about 48 and 35 per cent lower union intensities for women and men, respectively. Similar to model A, we found that the negative impact of enrolment on union formation rates is lower in the final year of education, i.e., non-working students exhibit union formation intensities which are only by about 35 and 41 per cent lower for women and men, respectively, while female and male students who work enter a first union by about 17 and 23 per cent less often in their final year at school than those who just finished school and started their first job. By distinguishing between working status for those enrolled, we could show that those who already combine student and working roles enter a union more often than do nonworking students, but less frequently than do those who are not enrolled and work. However, due to data limitations, we neither distinguished between full-time and part-time education nor between full-time and part-time employment, and those who combine school and work probably might be involved part-time in at least one of these schemes.

Concerning the difficulties in the transition to employment, our results demonstrate that women who did not take up work during the first three years after leaving school only show slightly lower union formation rates as compared to those who just began to work (-6 per cent). However, if the period between leaving school and entering employment is longer than three years, the negative effect increases to 21 per cent. In contrast, the status of "left school but not yet working" has a much stronger negative impact on union formation intensities for men. Indeed, union formation rates for non-working males who left school less than three years ago are by about 30 per cent lower, and union formation intensities are even about 61 per cent lower for those who left education more than three years ago. The latter effect is of a similar order as the one for non-working students!

The gender difference confirms our hypothesis, which is in line with the arguments of Oppenheimer and colleagues who claim that men's career and career maturity play a more important role for the timing of marriage than do women's. Similarly, Goldscheider and Waite (1986) found that employment has a stronger impact on the marriage intensities of men than on that of women.

Concerning the impact of non-students' work experience on entry into a first union we found that the more work experience they have, the higher their union formation rates are. In particular being employed for two years already increases the union formation risk by about seven and five per cent for women and men, respectively. The third year of work experience already raises the union formation rates by about 16 and 12 per cent for females and males, respectively, while having worked for three and more years increases the union formation intensities by about 22 and 26 per cent for women and men, respectively, as compared to those in the first year of employment. Differently to our hypothesis, we found almost no difference between male and female non-students with regard to the effect of work experience. 
In the next step, we intended to investigate trends in the gender differences regarding the effects of level of education, enrolment and employment status. Therefore, we also considered how these explanatory variables interacted with the calendar period. As mentioned earlier, we modelled the calendar period for the interaction using a spline with a node in the period 1975-1979. The estimated slope of spline segments yields the average change of the effect over time in the respective period relative to 1975-1979.

Table 3 shows the estimated coefficients for the interaction between the effect of educational attainment and calendar period for selected periods, i.e., 1955-1964, 19751979, and 1995-1998. In order to better evaluate whether the social differences among men and women become more similar, we plotted the interaction effects relative to the baseline level (short secondary studies BEPC) within the same period in Figure 2. We found that men and women having a BEPC degree entered a first union less frequently in 1955-64 and 1995-98 as compared to the mid-1970s. Moreover, in the most recent period, men with a BEPC formed a first union slightly less frequently than their female peers.

As can be seen in Figure 2, the effect of low and medium education levels clearly changed over time for women, while the relative effect of a university degree is pretty stable for them. In the earliest period, having a primary or no degree at all even had a positive effect on female union formation as compared to having a BEPC. Hence, the effect of the educational level was slightly U-shaped during 1955-1964. However, between 1955-1964 and 1975-1979, the effect of only having a primary or no degree at all turned negative as compared to having a BEPC, and ever since that time, we can observe that the effect of education on entry into a first union is also increasing for women.

The effect of educational level on male union formation increases from primary to secondary and tertiary level for all periods. The only exception is the BEP, although the difference between primary or no degree and BEPC is negligible for the earliest period. However, similar to the female union formation rates, the impact of the lowest level of education on male union formation strongly decreased between 1955-1964 and 19751979, and since then, the effect of union formation is clearly increasing for males. Summing up, our data show that the gender differences with respect to educational level diminished over time, although the pattern was already rather similar in the earliest period.

Concerning the interaction of enrolment and working status, we found more pronounced gender differences. Since enrolment and labour force participation were subject to tremendous changes in the past decades, we also expected more pronounced changes in the effect of enrolment and working status on union formation rates.

Table 4 summarises the estimated effects of the interaction between calendar period, enrolment and employment status for the periods 1955-1964, 1975-1979, and 1995-1998. We found that male school graduates entered a first union less often in 1955-1964 and in 1995-98 as compared to 1975-79, while the union formation pattern of their female counterparts remained unchanged since the mid-1970s.

Figure 3 graphically visualises these interaction effects relative to the baseline level (left school and first year working) within the calendar periods. Female union formation 
rates have changed a lot since 1955, particularly for non-working women who finished their education, while the pattern was rather stable for non-working female students. During 1955-1964, women who had completed their schooling but had not yet found a job even formed unions more frequently than those who started to work after graduation. Moreover, female union formation rates during 1955-1964 increased with the duration of being unemployed after graduation. This result is in line with earlier studies (Blossfeld and Huinink 1991; Liefbroer and Corijn 1999), which show that unemployment does not necessarily hamper union formation for women.

However from 1955-1962 to 1975-1979, female union formation intensities of nonworking non-students decreased as compared to those of women who had just started to work after their graduation. While non-working women who left school less than three years ago show only slightly higher union formation rates, those who left school more than three years ago already display significantly lower values than their working peers. The increasing importance of working status is a trend that also continued during 1975-1979 to 1995-1998, with non-working women showing significantly lower values of union risk in the last period. In all periods, male union formation intensities of non-working nonstudents were lower than those of working non-students. In the latter group, the working status increasingly gained importance, especially if the men had graduated more than three years ago. This confirms the convergence hypothesis with respect to the working status for people not involved in education.

As mentioned earlier, the union formation rates of non-working female students hardly changed from 1955 to 1998 as compared to those for working school graduates. In contrast, the male rates for non-working students in their final year significantly decreased over time, as indicated by relative values of union formation that are lower than those for women as early as 1975-1979 and 1995-1998. This may reflect the growing importance of working status for men. Moreover, Robert-Bobée and Mazuy (2004) argue that this norm is particularly binding for men, since women now more often form a union before finishing their studies. This phenomenon is particularly pronounced if they enter a union with an older man, who has already established himself in his job. Hence, we even find evidence for increasing divergence in union formation for non-working female and male students. Figure 3 also illustrates the change in the effect of work experience for non-students over time. In 1955-1964, work experience had a positive effect on union formation rates for both sexes. While an additional year of work experience raised the union formation risk between 25 to 32 per cent for women, the increase for the first two additional years of work experience was less steep for men (around 12 per cent per year). However, if men already had more than three years of work experience, their union formation rates were around 90 per cent higher than at the time they took on their first job. The less steep increase in the initial years of employment may reflect the pace and difficulties encountered in obtaining a stable job, and the higher importance of work for men outlined by Oppenheimer and Lewin (1999).

However, the impact of longer work experience diminished over time, as can be seen in Figure 3. While its positive effect has prevailed for men up to the recent period, it has vanished for women. Hence, work experience still has a different impact on men's and women's entry into a first union. 


\subsection{First Parenthood}

Table 5 shows the parameter estimates for the entry into parenthood for men and women. We controlled for age, number of siblings, father's socio-professional status, union status, level of education, the interaction of enrolment and working status, and calendar period.

Most of the covariates had the expected effects. With growing age, the first conception rates exhibit a bell-shaped pattern for both men and women. Gender differences are particularly pronounced before age 25 , with women showing higher rates of having a first child. Above age 30, men's chances to have a first child are somewhat higher.

The size of the family of origin has a significant impact on the timing of first births for both men and women. The larger the family of origin, the higher is the risk of having a first child. In contrast, the father's socio-professional status has no effect if we control for the respondent's socio-economic characteristics.

Union status has a strong effect on the risk of having a first child. Individuals who do not live in a union tend to avoid a pregnancy. Compared to a consensual union, the odds of conceiving a first child are 77 per cent lower for women, and 82 per cent lower for men who do not live in such a union. The risk to have a first child is two times higher for married men and women than for cohabiting partners.

The effect of the level of education is U-shaped for females; women with a primary or no degree and university graduates have the highest rates of entry into motherhood. Male university graduates also have significantly higher first conception rates as compared to their peers with other educational levels. However, being enrolled significantly lowers the risk of entering parenthood for men and women, with the effect being stronger for females than for males.

Working status has a negative effect for women, but a positive one for men. Hence, non-working women show higher rates of having a first child than their peers doing their first year of work. However, for men, entering the labour market seems to be a prerequisite for their transition to fatherhood. The time spent on the labour market speeds up the transition into parenthood for those who are working, be they men or women.

In a next step, we wanted to explore how the aforementioned effects of educational attainment and employment on the rates of having a first child changed over time by adding an interaction of these covariates with period. As in the analysis of union formation, we modelled the calendar period for the interaction using a spline with a node in the period 1975-1979. The estimated slope of spline segments yields the average change of the effect over time for the respective period relative to 1975-1979.

Figure 4 depicts the educational level effects for men and women for selected periods. Contrary to our hypothesis, we found similar effects of educational level for men and women, which changed in the same way over time. In 1955-1964, highly educated men and women quickly progressed into parenthood. Since the mid-1970s, there has been no specific effect of educational level for men and women. However, for individuals 
having a BEPC degree, the trend over the calendar period has been decreasing for men and women, which has come to a halt since the mid-1970s for women with a BEPC (cf. Table $6)$.

Figure 5 shows the interaction of period with enrolment and employment status. Our data show that the gender differences regarding the negative effect of enrolment for people who still have more than one year until graduation narrowed, while the differences reversed for those in their final year of schooling. This change is similar to the one for the entry into first union.

As mentioned above, non-working women, unlike men, have higher conception rates than those who just started to work, but the differences have diminished in the most recent period. Regarding work experience, our assumption was confirmed that the time a person has worked on the labour market has an increasingly strong effect on the rate of having a first child. We did not find any pronounced gender differences in the effects of work experience for all periods. However, the rates of having a first child for men and women in their first year at work were decreasing over time, with a much steeper decline for men since the mid-1970s (cf. Table 7).

\section{Summary}

In this paper, we investigated the differences in men's and women's family formation over time. Using event history techniques and based on data from the EHF 1999, we studied how the educational level attained, enrolment and employment status affect the risk of entering a first union or having a first child for men and women in France. Relying on theoretical arguments and existing empirical studies we formulated three hypotheses about the gender differences regarding the impact of educational attainment, enrolment and working status on union formation. Moreover, we assumed that this gender-specific impact changed over time. In particular, we hypothesised that the gender differences narrowed over time and there was convergence in the impact of educational attainment, enrolment and employment on the union formation of males and females.

Concerning the educational level attained, we assumed a positive effect for men, but a negative or U-shaped for women. However, we found that the educational level became increasingly important for union formation rates of both men and women. We only found a negative impact on the entry into a first union for men at the lowest educational level, but no significant effect for women. Hence, except for the lowest educational level, our data do not indicate gender differences. However, when investigating how the effects changed over time, we could show that the effect of the lowest educational level also turned negative for women between 1955-1964 and 1975-1979. Regarding entry into first parenthood we even found similar effects for all periods. Our data thus support the convergence hypothesis regarding the effect of educational level attained, although the pattern was already rather similar for men and women in the earliest period.

In our second hypothesis, we assumed that the effect of educational enrolment is stronger for women than it is for men, and that it is smaller for both sexes in the final year 
of education. Moreover, we assumed that the negative impact of enrolment has decreased in the recent period. Our data confirmed the gender difference regarding the negative impact as well as the weaker effect in the last year before graduation. While the gender difference regarding the impact of enrolment on the risk of first conception narrowed, it remained stable for entry into the first union for female and male students who still need more than one year to complete their studies. However, family formation rates for nonworking male students in their final year of education significantly decreased over time, reaching even lower values than those for women in 1975-1979 and 1995-1998. Hence, the impact of educational enrolment in the final year of schooling even reversed for the two sexes. This may reflect a greater importance of working status for male students shortly before graduation, while it may have become less binding for women in the recent period, because more women now tend to form a union before finishing their studies, in particular if they enter a union with an older man, who has already established himself in his job (Robert-Bobée and Mazuy 2004).

The third set of hypotheses deals with gender differences regarding the effect of employment. We focused on two different effects of employment on family formation, namely the impact of employment status per se (i.e., working and not working) and the effect of work experience. For both effects, we assumed that the impact was greater for men than for women, but found that the difference was more pronounced in the earlier periods.

Our data confirm the hypothesis of gender differences with respect to difficulties in the transition from school to work. We found that the status of not working has a very strong negative impact on family formation rates for males, which significantly increases with the time that elapsed since their graduation. The effect was considerably smaller for women and even positive for entry into first union in the earliest period. For non-working women the risk to have a first child is even higher than for their peers in their first year of work. Our results are in line with the arguments of Oppenheimer and colleagues that men's working position plays a more important role for the timing of a marriage than does women's (Oppenheimer and Lewin 1999). Moreover, our findings confirm the results of Blossfeld and Huinink (1991) and Liefbroer and Corijn (1999) that, for women, being unemployed does not necessarily delay the entry into a union or having a first child. However, since 1955-1964, the working status has also increasingly gained importance for women's entering into a union, with non-working women showing significantly lower union formation rates in the last period. This confirms the convergence hypothesis with respect to the working status.

Furthermore, our study shows that the impact of work experience on first union formation and first parenthood increases with a longer duration of employment. Contrary to our hypothesis, we found almost no gender differences in the impact of work experience for all periods taken together. However, when taking into account how the impact of work experience changed over time, we saw that, in the most recent period, the effect has become weaker for men and has almost disappeared for women regarding their entry into a first union. For the transition to first parenthood, the effect of work experience has become stronger. In sum, the changes in the effects of work experience on family formation were similar for men and women. 
The large sample size would permit us to refine our analysis even more. In particular, we could test whether the effects of educational attainment, enrolment and employment status changed for specific groups, i.e., for children of high-level white-collar workers, individuals with a university degree, etc., in order to identify the social groups that are in the vanguard of the change in the transition to adulthood.

Moreover, the analysis could be extended by adopting a 'holistic' approach and studying the life course sequence of such events as finishing education, entering the labour market, forming a union, marrying and having a first child. By using sequence analysis, we could study whether men's and women's sequences are also converging and whether the social differences between their life course sequences have become smaller. 


\section{References}

Baizán, P., A. Aassve, and F. Billari. 2004. 'The Interrelations Between Cohabitation, Marriage and First Birth in Germany and Sweden'. Population and Environment 25(6): 531-561.

Beaumel C., F. Daguet, L. Richet-Mastain and M. Vatan. 2006. La situation démographique en 2004: mouvement de la population. Paris : INSEE, p. 369. http://www.insee.fr/fr/ppp/ir/accueil.asp?page=sd2004/synt/synthese.htm

Becker, G.S. 1976. The Economic Approach to Human Behaviour. Chicago: University of Chicago Press.

Becker, G.S. 1981. A Treatise on the Family. Cambridge: Harvard University Press.

Billari, F.C. and D. Philipov. 2004. Women's education and entry into a first union: A simultaneous-hazard comparative analysis of Central and Eastern Europe. Vienna Yearbook of Population Research 2004.

Blossfeld, H.-P. and J. Huinik. 1991. Human Capital Investments or Norms of Role Transition? How Women's Schooling and Career Affect the Process of Family Formation. American Journal of Sociology 97(1): 143-68.

Blossfeld, H.-P. and U. Jaenichen. 1992. Educational Expansion and Changes in Women's Entry into Marriage and Motherhood in the Federal Republic of Germany. Journal of Marriage and the Family 54: 302-315.

Blossfeld, H.-P. and G. Rohwer. 2002. Techniques of Event History Modeling: New Approaches to Causal Analysis. $2^{\text {nd }}$ Edition. Majwah, NJ: Lawrence Earlbaum Associates.

Buber, I. 2002. Recent fertility trends in Austria. PhD thesis. Vienna University of Technology.

Brien, M.J., L.A. Lillard, and L.J. Waite. 1999. Interrelated Family-Building Behaviors: Cohabitation, Marriage, and Nonmarital Conception. Demography 36(4): 535-551.

Brüderl, J. and A. Diekmann. 1994. Bildung, Geburtskohorte und Heiratsalter: Eine vergleichende Untersuchung des Heiratsverhaltens in Westdeutschland, Ostdeutschland und den Vereinigten Staaten. Zeitschrift für Soziologie 23: 56-73.

Cassan F., Héran F., Toulemon L. 2000, Study of family history. France's 1999 Family Survey. Courrier des statistiques, English series, n 6, 2000 annual issue: 7-19.

Cherlin, A. 2000. Toward a new home socioeconomics of union formation. In: Waite, L.J. (ed), The Ties that Bind: Perspectives on Marriage and Cohabitation. New York: Aldine de Gruyter. 
Coppola, L. 2004. Education and union formation as simultaneous processes in Italy and Spain. European Journal of Population 20, 219-250.

Courgeau, D. and E. Lelièvre. 1986. Nuptialité et agriculture. Population 2: 303-326.

EURYDICE. 2005. Summary sheets on education systems in Europe: France. Last update: January 2005. www.eurydice.org.

Gauthier, A.H. 1996. The State and the Family: A Comparative Analysis of Family Policies in Industrialized Countries. Oxford: Clarendon Press.

Goldscheider, F.K. and L.J. Waite. 1986. Sex Differences in the Entry into Marriage. American Journal of Sociology 92(1): 91-109.

Goldstein, J.R. 2002. On the Tempo and Quantum of First Marriage. Draft.

Grenet, J. 2004. Is it Enough to Increase Compulsory Schooling to Raise Earnings? Evidence from the French Berthoin Reform. Working Paper. ENS-EHESS, Paris-Jourdan.

Hoem, J.M. 1986. The Impact of Education on Modern Family-Union Initiation. European Journal of Population 2: 113-133.

Huinink, J. 1995. Education, work, and family patterns of men: The case of West Germany. In: Blossfeld, H.-P. (ed.), The New Role of Women: Family Formation in Modern Societies. Boulder: Westview Press, pp. 247-262.

ILO. 2003. Key Indicators of Labour Market, $3^{\text {rd }}$ edition. CD-Rom. Geneva: International Labour Office.

Kravdal, Ø. 1999. Does Marriage Require a Stronger Economic Underpinning than Informal Cohabitation? Population Studies 53: 63-80.

Leridon, H. and L. Toulemon. 1995. Country-Specific Studies on the Trends in Family Formation and the New Role of Women: France. In: Blossfeld, H.-P. (ed.), The New Role of Women: Family Formation in Modern Societies. Boulder: Westview Press, pp. 77-101.

Liefbroer, A.C. and M. Corijn. 1999. Who, What, Where, and When? Specifying the Impact of Educational Attainment and Labour Force Participation on Family Formation. European Journal of Population 15: 45-75.

McLaughlin D.K., D.T. Lichter, and G.M. Johnston. 1993. Some Women Marry Young: Transition to First Marriage in Metropolitan and Non Metropolitan Areas. Journal of Marriage and the Family 55(4): 827-838.

Meron M. and I. Widmer. 2002. Unemployment leads women to postpone the birth of their first child. Population - E, 2: 301-330 
Oppenheimer, V.K. 1988. A Theory of Marriage Timing. American Journal of Sociology 94: 563-591.

Oppenheimer, V.K. 1994. Women's Rising Employment and the Future of the Family in Industrial Societies. Population and Development Review 20(2): 293-342.

Oppenheimer, V.K. 2000. The Continuing Importance of Men's Economic Position in Marriage Formation. In: Waite, L.J. (ed), The Ties that Bind: Perspectives on Marriage and Cohabitation. New York: Aldine de Gruyter.

Oppenheimer, V.K., M. Kalmijn, and L. Nelson. 1997. Men’s Career Development and Marriage Timing during a Period of Rising Inequality. Demography 34(3): 311-330.

Oppenheimer, V.K and A. Lewin. 1999. Career development and marriage formation in a period of rising inequality: Who is at risk? What are their prospects? In: Booth, A. and A.C. Crouter, and M.J. Shanahan (eds.) Transitions to Adulthood in a Changing Economy: No Work, No Family, No Future? Westport, CT: Greenwood Press.

Preston, S.H. and A.T. Richards. 1975. The Influence of Women's Work Opportunities on Marriage Rates. Demography 12: 209-222.

Robert-Bobée, I. and M. Mazuy. 2003. Calendriers de constitution des familles et âge de fin des études. Documents de Travail. INSEE.

StataCorp. 2006. Stata Statistical Software: Release 9.2. College Station, TX: Stata Corporation.

Thornton, A., W.G. Axinn, and J.D. Teachman. 1995. The Influence of School Enrollment and Accumulation on Cohabitation and Marriage in Early Adulthood. American Sociological Review 60: 762-774.

Toulemon, L. 1995. The Place of Children in the History of Couples. Population: An English Selection 7: 163-186.

Toulemon, L. 1997. Cohabitation is here to stay. Population: An English Selection 9: 1156. 


\section{Tables and Figures}

Table 1

Model estimates for log hazards of entry into first union; selected models

\begin{tabular}{|c|c|c|c|c|}
\hline \multirow[t]{2}{*}{ Covariate } & \multicolumn{2}{|c|}{ Model A } & \multicolumn{2}{|c|}{ Model B } \\
\hline & Females & Males & Females & Males \\
\hline \multicolumn{5}{|l|}{ Age } \\
\hline 15 & $-4.304 * * *$ & $-6.248 * * *$ & $-4.296 * * *$ & $-6.220 * * *$ \\
\hline 16 & $-3.364 * * *$ & $-5.582 * * *$ & $-3.374 * * *$ & $-5.558 * * *$ \\
\hline 17 & $-2.544 * * *$ & $-4.463 * * *$ & $-2.567 * * *$ & $-4.437 * * *$ \\
\hline 18 & $-1.995^{* * *}$ & $-3.606 * * *$ & $-2.027 * * *$ & $-3.572 * * *$ \\
\hline 19 & $-1.722 * * *$ & $-3.056 * * *$ & $-1.760 * * *$ & $-3.014 * * *$ \\
\hline 20 & $-1.591 * * *$ & $-2.517 * * *$ & $-1.633^{* * *}$ & $-2.468 * * *$ \\
\hline 21 & $-1.548 * * *$ & $-2.102 * * *$ & $-1.594 * * *$ & $-2.050 * * *$ \\
\hline 22 & $-1.597 * * *$ & $-1.958 * * *$ & $-1.646 * * *$ & $-1.902 * * *$ \\
\hline 23 & $-1.699 * * *$ & $-1.888 * * *$ & $-1.749 * * *$ & $-1.831^{* * *}$ \\
\hline 24 & $-1.831^{* * *}$ & $-1.908^{* * *}$ & $-1.880 * * *$ & $-1.848 * * *$ \\
\hline 25 & $-1.979 * * *$ & $-1.993 * * *$ & $-2.029 * * *$ & $-1.931 * * *$ \\
\hline 26 & $-2.164 * * *$ & $-2.108 * * *$ & $-2.214 * * *$ & $-2.043 * * *$ \\
\hline 27 & $-2.268 * * *$ & $-2.204^{* * *}$ & $-2.320 * * *$ & $-2.138 * * *$ \\
\hline 28 & $-2.378 * * *$ & $-2.360 * * *$ & $-2.431 * * *$ & $-2.293 * * *$ \\
\hline 29 & $-2.479 * * *$ & $-2.467 * * *$ & $-2.532 * * *$ & $-2.399 * * *$ \\
\hline 30 & $-2.730 * * *$ & $-2.513^{* * *}$ & $-2.783 * * *$ & $-2.445^{* * *}$ \\
\hline 31 & $-2.820 * * *$ & $-2.721^{* * *}$ & $-2.874 * * *$ & $-2.654 * * *$ \\
\hline 32 & $-2.858 * * *$ & $-2.879 * * *$ & $-2.911 * * *$ & $-2.812 * * *$ \\
\hline 33 & $-2.975^{* * *}$ & $-2.991 * * *$ & $-3.028 * * *$ & $-2.924 * * *$ \\
\hline 34 & $-3.272 * * *$ & $-3.052 * * *$ & $-3.324 * * *$ & $-2.985 * * *$ \\
\hline 35 & $-3.219 * * *$ & $-3.109 * * *$ & $-3.271 * * *$ & $-3.042 * * *$ \\
\hline 36 & $-3.322 * * *$ & $-3.310 * * *$ & $-3.375^{* * *}$ & $-3.243^{* * *}$ \\
\hline 37 & $-3.422 * * *$ & $-3.405^{* * *}$ & $-3.474 * * *$ & $-3.338 * * *$ \\
\hline 38 & $-3.576 * * *$ & $-3.360 * * *$ & $-3.628 * * *$ & $-3.294 * * *$ \\
\hline 39 & $-3.726 * * *$ & $-3.495 * * *$ & $-3.778 * * *$ & $-3.429 * * *$ \\
\hline \multicolumn{5}{|l|}{ Siblings } \\
\hline None & $-0.143^{* * *}$ & $-0.209 * * *$ & $-0.144 * * *$ & $-0.207 * * *$ \\
\hline 1 & 0.000 & 0.000 & 0.000 & 0.000 \\
\hline 2 & $0.028 * *$ & 0.018 & $0.028 * *$ & 0.018 \\
\hline 3 & $0.025 *$ & 0.020 & $0.023 *$ & 0.020 \\
\hline 4 & 0.012 & $0.042 *$ & 0.009 & $0.042 *$ \\
\hline 5 and more & 0.014 & 0.011 & 0.009 & 0.013 \\
\hline \multicolumn{5}{|l|}{ Socio-professional status of father } \\
\hline Inactive & 0.006 & -0.020 & 0.004 & -0.011 \\
\hline Farmer & -0.018 & $-0.127 * * *$ & -0.020 & $-0.126^{* * *}$ \\
\hline Self-employed & 0.010 & 0.025 & 0.009 & 0.025 \\
\hline Unskilled worker & 0.018 & -0.012 & 0.018 & -0.011 \\
\hline Skilled worker & 0.000 & 0.000 & 0.000 & 0.000 \\
\hline Low-level white-collar worker & -0.022 & 0.021 & -0.022 & 0.020 \\
\hline Medium-level white-collar worker & 0.006 & $0.041^{*}$ & 0.008 & $0.041^{*}$ \\
\hline High-level white-collar worker & -0.021 & $0.040 *$ & -0.017 & $0.039 *$ \\
\hline \multicolumn{5}{|l|}{ Pregnancy } \\
\hline Not pregnant/no child & 0.000 & 0.000 & 0.000 & 0.000 \\
\hline Pregnant & $2.085^{* * *}$ & $2.469 * * *$ & $2.082 * * *$ & $2.468 * * *$ \\
\hline Child & $0.155^{* * *}$ & $0.569 * * *$ & $0.154 * * *$ & $0.566^{* * *}$ \\
\hline
\end{tabular}

Legend: ${ }^{*} \mathrm{p}<0.05,{ }^{* *} \mathrm{p}<0.01,{ }^{* * *} \mathrm{p}<0.001$ 
Table 2 (continued)

Model estimates for log hazards of entry into first union; selected models

\begin{tabular}{|c|c|c|c|c|c|c|}
\hline & \multicolumn{2}{|c|}{ Model A } & \multicolumn{2}{|c|}{ Model B } \\
\hline \multicolumn{3}{|l|}{ covariate } & Females & Males & Females & Males \\
\hline \multicolumn{7}{|c|}{ Level of education attained } \\
\hline \multicolumn{3}{|c|}{ Primary } & -0.011 & $-0.176^{* * *}$ & -0.020 & $-0.172 * * *$ \\
\hline \multirow{4}{*}{\multicolumn{2}{|c|}{ Secondary }} & Short (BEPC) & 0.000 & 0.000 & 0.000 & 0.000 \\
\hline & & Long prof. apprenticeship (CAP) & $0.040 * *$ & $0.044 * *$ & $0.046^{* *}$ & $0.040 *$ \\
\hline & & Long professional studies (BEP) & $0.081^{* * *}$ & 0.025 & $0.086 * * *$ & 0.017 \\
\hline & & Completed (Baccalauréat) & $0.117 * * *$ & $0.117 * * *$ & $0.127 * * *$ & $0.104 * * *$ \\
\hline \multicolumn{3}{|c|}{ Tertiary } & $0.432 * * *$ & $0.422 * * *$ & $0.443^{* * *}$ & $0.396 * * *$ \\
\hline \multicolumn{7}{|c|}{ Calendar period } \\
\hline \multicolumn{3}{|c|}{$1955-1964$} & $-0.226 * * *$ & $-0.242 * * *$ & $-0.232 * * *$ & $-0.238 * * *$ \\
\hline \multicolumn{3}{|c|}{ 1965-1969 } & $-0.130 * * *$ & 0.013 & $-0.131 * * *$ & 0.013 \\
\hline \multicolumn{3}{|c|}{ 1970-1974 } & $-0.039 * *$ & $0.034^{*}$ & $-0.037 * *$ & $0.034^{*}$ \\
\hline \multicolumn{3}{|c|}{$1975-1979$} & 0.000 & 0.000 & 0.000 & 0.000 \\
\hline \multicolumn{3}{|c|}{ 1980-1984 } & $-0.059 * * *$ & $-0.066 * * *$ & $-0.061 * * *$ & $-0.065 * * *$ \\
\hline \multicolumn{3}{|c|}{ 1985-1989 } & $-0.141 * * *$ & $-0.214^{* * *}$ & $-0.143^{* * *}$ & $-0.213 * * *$ \\
\hline \multicolumn{3}{|c|}{ 1990-1994 } & $-0.084^{* * *}$ & $-0.213^{* * *}$ & $-0.086^{* * *}$ & $-0.211^{* * *}$ \\
\hline \multicolumn{3}{|c|}{ 1995-1998 } & $-0.121 * * *$ & $-0.263 * * *$ & $-0.127 * * *$ & $-0.260 * * *$ \\
\hline \multicolumn{7}{|c|}{ Enrolment status } \\
\hline \multicolumn{3}{|c|}{ More than 1 year to graduation } & $-1.231 * * *$ & $-0.558 * * *$ & & \\
\hline \multicolumn{3}{|c|}{ In final year of school } & $-0.306 * * *$ & $-0.119 * * *$ & & \\
\hline \multicolumn{3}{|c|}{ Left school less than 1 year ago } & 0.000 & 0.000 & & \\
\hline \multicolumn{3}{|c|}{ Left school between 1 and 2 years ago } & $-0.034 *$ & $0.090 * * *$ & & \\
\hline \multicolumn{3}{|c|}{ Left school between 2 and 3 years ago } & $-0.048 * *$ & $0.087 * *$ & & \\
\hline \multicolumn{3}{|c|}{ Left school more than 3 years ago } & $-0.125 * * *$ & $0.081^{* *}$ & & \\
\hline Employm & nt $s$ & atus & & & & \\
\hline Not wo & king & & $-0.171 * * *$ & $-0.450 * * *$ & & \\
\hline $1^{\text {st }}$ year & vorl & & 0.000 & 0.000 & & \\
\hline $2^{\text {nd }}$ year & wor & ing & $0.090 * * *$ & 0.007 & & \\
\hline $3^{\text {rd }}$ year & worl & & $0.183^{* * *}$ & $0.067 *$ & & \\
\hline 3 and $m$ & ore & ears working & $0.271 * * *$ & $0.199 * * *$ & & \\
\hline Enrolmen & anc & employment status interaction & & & & \\
\hline & & e than 1 year to graduation & & & $-1.447 * * *$ & $-1.060 * * *$ \\
\hline 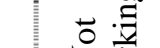 & & nal year of school & & & $-0.432 * * *$ & $-0.537 * * *$ \\
\hline 乙穷 & & school less than 3 years ago & & & $-0.063 * * *$ & $-0.356 * * *$ \\
\hline & & school more than 3 years ago & & & $-0.237 * * *$ & $-0.966 * * *$ \\
\hline & & e than 1 year to graduation & & & $-0.669 * * *$ & $-0.437 * * *$ \\
\hline & & l year of school & & & $-0.199 * * *$ & $-0.279 * * *$ \\
\hline 番 & Le & school; working $1^{\text {st }}$ year & & & 0.000 & 0.000 \\
\hline$\overline{0}$ & & school; working $2^{\text {nd }}$ year & & & $0.073^{* * *}$ & 0.046 \\
\hline & Le & school; working $3^{\text {rd }}$ year & & & $0.151^{* * *}$ & $0.102 * * *$ \\
\hline & Le & school; working 3 and more years & & & $0.200 * * *$ & $0.223 * * *$ \\
\hline Log-likelil & ood & & -107223 & -56027 & -107013 & -55950 \\
\hline Bayesian I & forr & ation Criteria & 215341 & 112935 & 214921 & 112782 \\
\hline
\end{tabular}

Legend: ${ }^{*} \mathrm{p}<0.05,{ }^{* *} \mathrm{p}<0.01,{ }^{* * *} \mathrm{p}<0.001$ 
Table 3

Estimated effects of the interaction between educational level and time period on entry into first union

\begin{tabular}{|c|c|c|c|c|}
\hline \multicolumn{2}{|c|}{ Educational level } & 1955-1964 & 1975-1979 & 1995-1998 \\
\hline \multicolumn{5}{|c|}{ Women } \\
\hline \multicolumn{2}{|l|}{ Primary } & $-0.225 * * *$ & $-0.103^{* * *}$ & $-0.685 * * *$ \\
\hline \multirow{4}{*}{ Secondary } & Short (BEPC) & $-0.378 * * *$ & 0.000 & $-0.242 * * *$ \\
\hline & Long prof. apprenticeship (CAP) & $-0.254 * * *$ & -0.004 & $-0.586 * * *$ \\
\hline & Long professional studies (BEP) & $-0.323 * * *$ & $0.056 *$ & $-0.526 * * *$ \\
\hline & Completed (Baccalauréat) & $-0.296 * * *$ & $0.060 * *$ & $-0.522 * * *$ \\
\hline \multicolumn{2}{|l|}{ Tertiary } & $0.160 * * *$ & $0.330 * * *$ & $-0.252 * * *$ \\
\hline \multicolumn{5}{|l|}{ Men } \\
\hline \multicolumn{2}{|l|}{ Primary } & $-0.372 * * *$ & $-0.252 * * *$ & $-0.873 * * *$ \\
\hline \multirow{4}{*}{ Secondary } & Short (BEPC) & $-0.363 * * *$ & 0.000 & $-0.297 * * *$ \\
\hline & Long prof. apprenticeship (CAP) & $-0.272 * * *$ & 0.020 & $-0.601 * * *$ \\
\hline & Long professional studies (BEP) & $-0.272 * *$ & -0.004 & $-0.625 * * *$ \\
\hline & Completed (Baccalauréat) & $-0.168 * * *$ & $0.079 * *$ & $-0.542 * * *$ \\
\hline \multicolumn{2}{|l|}{ Tertiary } & $0.120 *$ & $0.377 * * *$ & $-0.244^{*}$ \\
\hline
\end{tabular}

Legend: ${ }^{*} \mathrm{p}<0.05,{ }^{* *} \mathrm{p}<0.01,{ }^{* * *} \mathrm{p}<0.001$.

Table 4

Estimated effects of the interaction between enrolment $\mathrm{X}$ working status and time period on entry into first union

\begin{tabular}{|c|c|c|c|c|}
\hline \multicolumn{2}{|c|}{ Enrolment X Working status } & 1955-1964 & 1975-1979 & 1995-1998 \\
\hline \multicolumn{5}{|c|}{ Women } \\
\hline \multirow{4}{*}{ 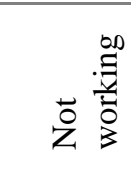 } & More than 1 year to graduation & $-2.211 * * *$ & $-1.379 * * *$ & $-1.554 * * *$ \\
\hline & In final year of school & $-1.164 * * *$ & $-0.353^{* * *}$ & $-0.517 * * *$ \\
\hline & Left school less than 3 years ago & $-0.449 * * *$ & $0.062 *$ & $-0.353 * * *$ \\
\hline & Left school more than 3 years ago & 0.012 & $-0.389 * * *$ & $-0.657 * * *$ \\
\hline \multirow{6}{*}{ 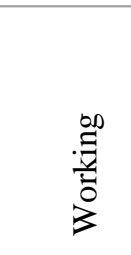 } & More than 1 year to graduation & $-1.042 * * *$ & $-0.634 * * *$ & $-0.888 * * *$ \\
\hline & In final year of school & $-0.514 * * *$ & $-0.188 * *$ & $-0.551 *$ \\
\hline & Left school; working $1^{\text {st }}$ year & $-0.617 * * *$ & 0.000 & 0.025 \\
\hline & Left school; working $2^{\text {nd }}$ year & $-0.347 * * *$ & $0.110^{* * *}$ & -0.060 \\
\hline & Left school; working $3^{\text {rd }}$ year & $-0.066^{*}$ & $0.141^{* * *}$ & -0.054 \\
\hline & Left school; working $3+$ years & $0.151^{* * *}$ & $0.083 * * *$ & -0.007 \\
\hline \multicolumn{5}{|c|}{ 等 } \\
\hline \multirow{4}{*}{ 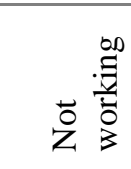 } & More than 1 year to graduation & $-1.684 * * *$ & $-1.021 * * *$ & $-1.468 * * *$ \\
\hline & In final year of school & $-0.928 * * *$ & $-0.540 * * *$ & $-0.999 * * *$ \\
\hline & Left school less than 3 years ago & $-0.665 * * *$ & $-0.384 * * *$ & $-0.801 * * *$ \\
\hline & Left school more than 3 years ago & $-0.920 * * *$ & $-1.007 * * *$ & $-1.464 * * *$ \\
\hline \multirow{6}{*}{ 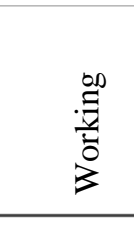 } & More than 1 year to graduation & $-0.885 * * *$ & $-0.441 * * *$ & $-1.095 * * *$ \\
\hline & In final year of school & $-0.602 * *$ & -0.148 & -0.789 \\
\hline & Left school; working $1^{\text {st }}$ year & $-0.642 * * *$ & 0.000 & $-0.389 * * *$ \\
\hline & Left school; working $2^{\text {nd }}$ year & $-0.554 * * *$ & -0.007 & $-0.284 * * *$ \\
\hline & Left school; working $3^{\text {rd }}$ year & $-0.458 * * *$ & 0.080 & $-0.289 * * *$ \\
\hline & Left school; working $3+$ years & -0.019 & $0.074 *$ & $-0.117 * *$ \\
\hline
\end{tabular}

Legend: ${ }^{*} \mathrm{p}<0.05,{ }^{* *} \mathrm{p}<0.01,{ }^{* * *} \mathrm{p}<0.001$. 


\section{Table 5}

Model estimates for log hazards of entry into first parenthood

\begin{tabular}{|c|c|c|}
\hline \multirow[t]{2}{*}{ Covariate } & \multicolumn{2}{|l|}{ Model B } \\
\hline & Females & Males \\
\hline \multicolumn{3}{|l|}{ Age } \\
\hline 15 & $-3.178 * * *$ & $-4.926 * * *$ \\
\hline 16 & $-2.494 * * *$ & $-4.410 * * *$ \\
\hline 17 & $-2.067 * * *$ & $-3.637 * * *$ \\
\hline 18 & $-1.894 * * *$ & $-2.906 * * *$ \\
\hline 19 & $-1.951 * * *$ & $-2.583 * * *$ \\
\hline 20 & $-2.119 * * *$ & $-2.432 * * *$ \\
\hline 21 & $-2.241 * * *$ & $-2.234 * * *$ \\
\hline 22 & $-2.312 * * *$ & $-2.273 * * *$ \\
\hline 23 & $-2.380 * * *$ & $-2.339 * * *$ \\
\hline 24 & $-2.379 * * *$ & $-2.416 * * *$ \\
\hline 25 & $-2.426 * * *$ & $-2.368 * * *$ \\
\hline 26 & $-2.471 * * *$ & $-2.448 * * *$ \\
\hline 27 & $-2.525 * * *$ & $-2.426 * * *$ \\
\hline 28 & $-2.598 * * *$ & $-2.466 * * *$ \\
\hline 29 & $-2.677 * * *$ & $-2.537 * * *$ \\
\hline 30 & $-2.791 * * *$ & $-2.633 * * *$ \\
\hline 31 & $-2.934 * * *$ & $-2.733 * * *$ \\
\hline 32 & $-3.120 * * *$ & $-2.825 * * *$ \\
\hline 33 & $-3.223 * * *$ & $-2.987 * * *$ \\
\hline 34 & $-3.428 * * *$ & $-3.113^{* * *}$ \\
\hline 35 & $-3.701 * * *$ & $-3.206 * * *$ \\
\hline 36 & $-3.734 * * *$ & $-3.535 * * *$ \\
\hline 37 & $-4.033 * * *$ & $-3.699 * * *$ \\
\hline 38 & $-4.462 * * *$ & $-3.877 * * *$ \\
\hline 39 & $-4.834 * * *$ & $-3.927 * * *$ \\
\hline \multicolumn{3}{|l|}{ Siblings } \\
\hline None & $-0.033^{*}$ & $-0.097 * * *$ \\
\hline 1 & 0.000 & 0.000 \\
\hline 2 & $0.085 * * *$ & $0.050 * *$ \\
\hline 3 & $0.150 * * *$ & $0.130 * * *$ \\
\hline 4 & $0.223 * * *$ & $0.162 * * *$ \\
\hline 5 and more & $0.269 * * *$ & $0.219 * * *$ \\
\hline \multicolumn{3}{|l|}{ Socio-professional status of father } \\
\hline Inactive & 0.062 & $0.306 * *$ \\
\hline Farmer & -0.003 & 0.032 \\
\hline Self-employed & 0.016 & 0.010 \\
\hline Unskilled worker & 0.016 & 0.021 \\
\hline Skilled worker & 0.000 & 0.000 \\
\hline Low-level white-collar worker & -0.019 & -0.029 \\
\hline Medium-level white-collar worker & $-0.028 *$ & -0.034 \\
\hline High-level white-collar worker & -0.007 & -0.002 \\
\hline \multicolumn{3}{|l|}{ Pregnancy } \\
\hline No union & $-1.463 * * *$ & $-1.746 * * *$ \\
\hline Cohabiting & 0.000 & 0.000 \\
\hline Married & $0.782 * * *$ & $0.840 * * *$ \\
\hline
\end{tabular}

Legend: ${ }^{*} \mathrm{p}<0.05,{ }^{* *} \mathrm{p}<0.01,{ }^{* * *} \mathrm{p}<0.001$. 
Table 4 (continued):

Model estimates for log hazards of entry into first parenthood

\begin{tabular}{|c|c|c|c|}
\hline \multicolumn{2}{|l|}{ Covariate } & \multicolumn{2}{|l|}{ Model B } \\
\hline & & Females & Males \\
\hline \multicolumn{4}{|c|}{ Level of education attained } \\
\hline \multicolumn{2}{|c|}{ Primary } & $0.058 * * *$ & -0.022 \\
\hline \multirow{4}{*}{ - } & Short (BEPC) & 0.000 & 0.000 \\
\hline & Long prof. apprenticeship (CAP) & $0.039 *$ & 0.006 \\
\hline & Long professional studies (BEP) & $0.051^{* * *}$ & 0.039 \\
\hline & Completed (Baccalauréat) & $-0.034^{* *}$ & -0.027 \\
\hline \multicolumn{2}{|c|}{ Tertiary } & $0.127 * * *$ & $0.206^{* * *}$ \\
\hline \multicolumn{4}{|c|}{ Calendar period } \\
\hline \multicolumn{2}{|c|}{ 1955-1964 } & $0.254 * * *$ & $0.352 * * *$ \\
\hline \multicolumn{2}{|c|}{$1965-1969$} & $0.220 * * *$ & $0.390 * * *$ \\
\hline \multicolumn{2}{|c|}{ 1970-1974 } & $0.230 * * *$ & $0.231 * * *$ \\
\hline \multicolumn{2}{|c|}{$1975-1979$} & 0.000 & 0.000 \\
\hline \multicolumn{2}{|c|}{$1980-1984$} & $-0.030 *$ & $-0.113^{* * *}$ \\
\hline \multicolumn{2}{|c|}{$1985-1989$} & 0.008 & $-0.124 * * *$ \\
\hline \multicolumn{2}{|c|}{$1990-1994$} & $0.048^{* * *}$ & $-0.109 * * *$ \\
\hline \multicolumn{2}{|c|}{ 1995-1998 } & -0.014 & $-0.204 * * *$ \\
\hline \multicolumn{4}{|c|}{ Enrolment and employment status interaction } \\
\hline \multirow{4}{*}{ 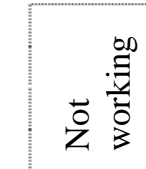 } & More than 1 year to graduation & $-1.757 * * *$ & $-1.169 * * *$ \\
\hline & In final year of school & $-0.304 * * *$ & $-0.375^{* * *}$ \\
\hline & Left school less than 3 years ago & $0.283 * * *$ & $-0.208 * * *$ \\
\hline & Left school more than 3 years ago & $0.427 * * *$ & $-0.410 * * *$ \\
\hline \multirow{6}{*}{ 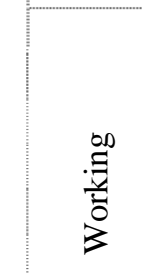 } & More than 1 year to graduation & $-0.796 * * *$ & $-0.398 * * *$ \\
\hline & In final year of school & -0.085 & -0.010 \\
\hline & Left school; working $1^{\text {st }}$ year & 0.000 & 0.000 \\
\hline & Left school; working $2^{\text {nd }}$ year & $0.220 * * *$ & $0.207 * * *$ \\
\hline & Left school; working $3^{\text {rd }}$ year & $0.344 * * *$ & $0.282 * * *$ \\
\hline & Left school; working 3 and more years & $0.482 * * *$ & $0.492 * * *$ \\
\hline \multicolumn{2}{|c|}{ Log-likelihood } & -80849 & -36697 \\
\hline \multicolumn{2}{|c|}{ Bayesian Information Criteria } & 162608 & 74287 \\
\hline
\end{tabular}

Legend: ${ }^{*} \mathrm{p}<0.05,{ }^{* *} \mathrm{p}<0.01,{ }^{* * *} \mathrm{p}<0.001$. 


\section{Table 6}

Estimated effects of the interaction between educational level and time period on entry into first parenthood

\begin{tabular}{|c|c|c|c|c|}
\hline \multicolumn{2}{|c|}{ Educational level } & $1955-1964$ & $1975-1979$ & 1995-1998 \\
\hline \multicolumn{5}{|c|}{ Women } \\
\hline \multicolumn{2}{|l|}{ Primary } & $0.251 * * *$ & $0.067 * *$ & 0.115 \\
\hline \multirow{4}{*}{ Secondary } & Short (BEPC) & $0.227 * * *$ & 0.000 & -0.009 \\
\hline & Long prof. apprenticeship (CAP) & $0.301^{* * *}$ & 0.007 & 0.055 \\
\hline & Long professional studies (BEP) & $0.476^{* * *}$ & -0.032 & 0.016 \\
\hline & Completed (Baccalauréat) & $0.466^{* * *}$ & $-0.083^{* * *}$ & -0.036 \\
\hline \multicolumn{2}{|l|}{ Tertiary } & $0.653 * * *$ & $0.167 * * *$ & $0.214^{* *}$ \\
\hline \multicolumn{5}{|l|}{ Men } \\
\hline Primary & & $0.291^{* * *}$ & -0.038 & $-0.312 * *$ \\
\hline \multirow{4}{*}{ Secondary } & Short $(B E P C)$ & $0.252 * * *$ & 0.000 & $-0.170 * * *$ \\
\hline & Long prof. apprenticeship (CAP) & $0.384 * * *$ & -0.025 & $-0.298 * *$ \\
\hline & Long professional studies (BEP) & $0.326^{* *}$ & 0.053 & -0.220 \\
\hline & Completed (Baccalauréat) & $0.519 * * *$ & $-0.066^{*}$ & $-0.339 * *$ \\
\hline Tertiary & & $0.803 * * *$ & $0.224 * * *$ & -0.049 \\
\hline
\end{tabular}

Legend: ${ }^{*} \mathrm{p}<0.05,{ }^{* *} \mathrm{p}<0.01,{ }^{* * *} \mathrm{p}<0.001$.

Table 7

Estimated effects of the interaction between enrolment X working status and time period on entry into first parenthood

\begin{tabular}{|c|c|c|c|c|}
\hline \multicolumn{2}{|c|}{ Enrolment X Working status } & 1955-1964 & 1975-1979 & 1995-1998 \\
\hline \multicolumn{5}{|c|}{ Women } \\
\hline \multirow{4}{*}{ 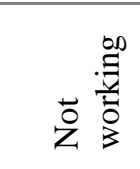 } & More than 1 year to graduation & $-1.342 * * *$ & $-1.511 * * *$ & $-2.394 * * *$ \\
\hline & In final year of school & -0.063 & $-0.181^{* * *}$ & $-0.805^{* * *}$ \\
\hline & Left school less than 3 years ago & $0.442 * * *$ & $0.354 * * *$ & -0.044 \\
\hline & Left school more than 3 years ago & $0.657 * * *$ & $0.292 * * *$ & $0.267 * * *$ \\
\hline \multirow{6}{*}{ 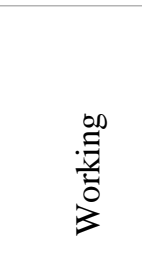 } & More than 1 year to graduation & $-0.377 * *$ & $-0.661 * * *$ & $-1.025 * *$ \\
\hline & In final year of school & 0.257 & -0.048 & -0.439 \\
\hline & Left school; working $1^{\text {st }}$ year & $0.245^{* * *}$ & 0.000 & $-0.312 * * *$ \\
\hline & Left school; working $2^{\text {nd }}$ year & $0.479 * * *$ & $0.177 * * *$ & -0.051 \\
\hline & Left school; working $3^{\text {rd }}$ year & $0.558 * * *$ & $0.274 * * *$ & $0.139 * * *$ \\
\hline & Left school; working 3+ years & $0.565 * * *$ & $0.331 * * *$ & $0.499 * * *$ \\
\hline \multicolumn{5}{|c|}{ 等 } \\
\hline \multirow{4}{*}{ 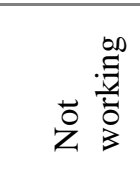 } & More than 1 year to graduation & $-0.551 * * *$ & $-0.994 * * *$ & $-2.626 * * *$ \\
\hline & In final year of school & $0.273 *$ & $-0.444 * * *$ & $-1.393 * * *$ \\
\hline & Left school less than 3 years ago & $0.421 * * *$ & $-0.194 *$ & $-1.221 * * *$ \\
\hline & Left school more than 3 years ago & -0.127 & $-0.612 * * *$ & $-0.853 * * *$ \\
\hline \multirow{6}{*}{ 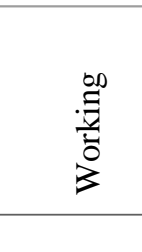 } & More than 1 year to graduation & -0.126 & $-0.416 * * *$ & $-1.252 * *$ \\
\hline & In final year of school & $0.795 * * *$ & -0.191 & $-1.956 * * *$ \\
\hline & Left school; working $1^{\text {st }}$ year & $0.278^{*}$ & 0.000 & $-0.821 * * *$ \\
\hline & Left school; working $2^{\text {nd }}$ year & $0.387 * * *$ & $0.133^{*}$ & $-0.410 * * *$ \\
\hline & Left school; working $3^{\text {rd }}$ year & $0.496 * * *$ & $0.203^{* * *}$ & $-0.364 * * *$ \\
\hline & Left school; working 3+ years & $0.552 * * *$ & $0.261^{* * *}$ & $0.193 * * *$ \\
\hline
\end{tabular}

Legend: ${ }^{*} \mathrm{p}<0.05,{ }^{* *} \mathrm{p}<0.01,{ }^{* * *} \mathrm{p}<0.001$. 


\section{Figure 1}

Estimated effects on first union intensities. The estimated values corresponding to age were shifted by a value of 6 in order to enhance visibility.

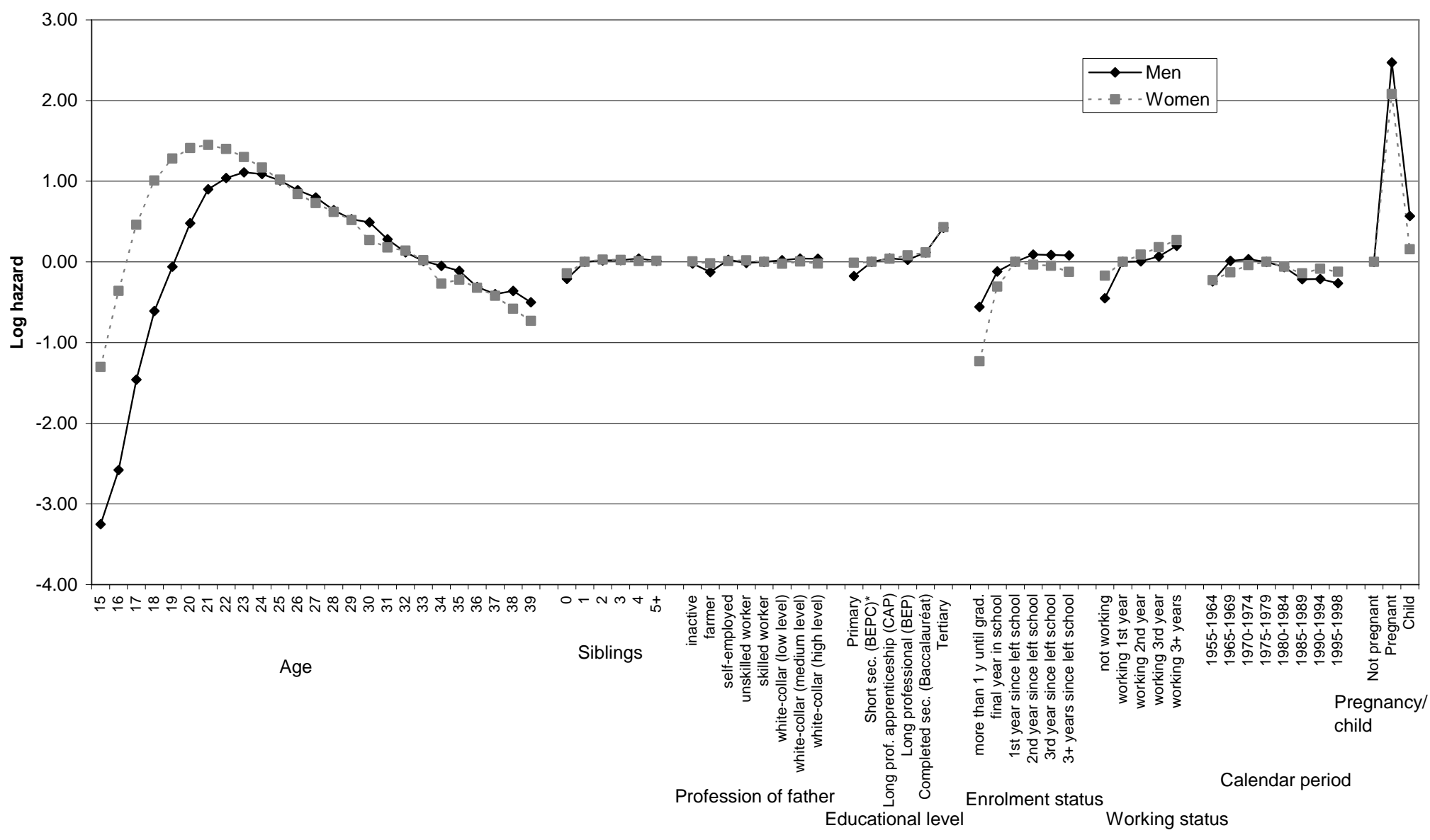




\section{Figure 2}

Estimated effects of level of education attained on entry into first union for selected years (without main period effect). The asterisk denotes the baseline category.

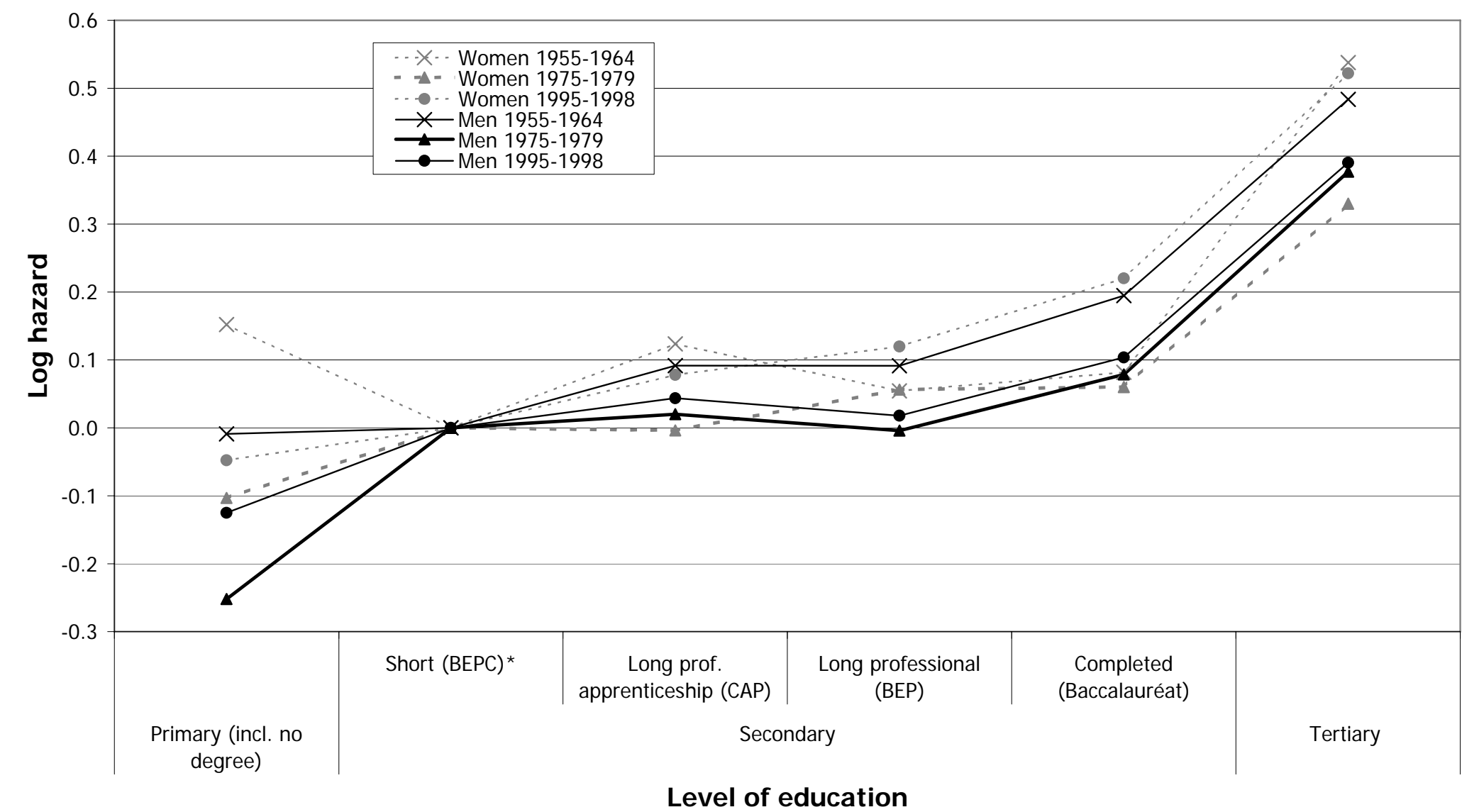




\section{Figure 3}

Estimated effects of interaction between enrolment and employment status on entry into first union for selected years (without main period effect). The asterisk denotes the baseline level.

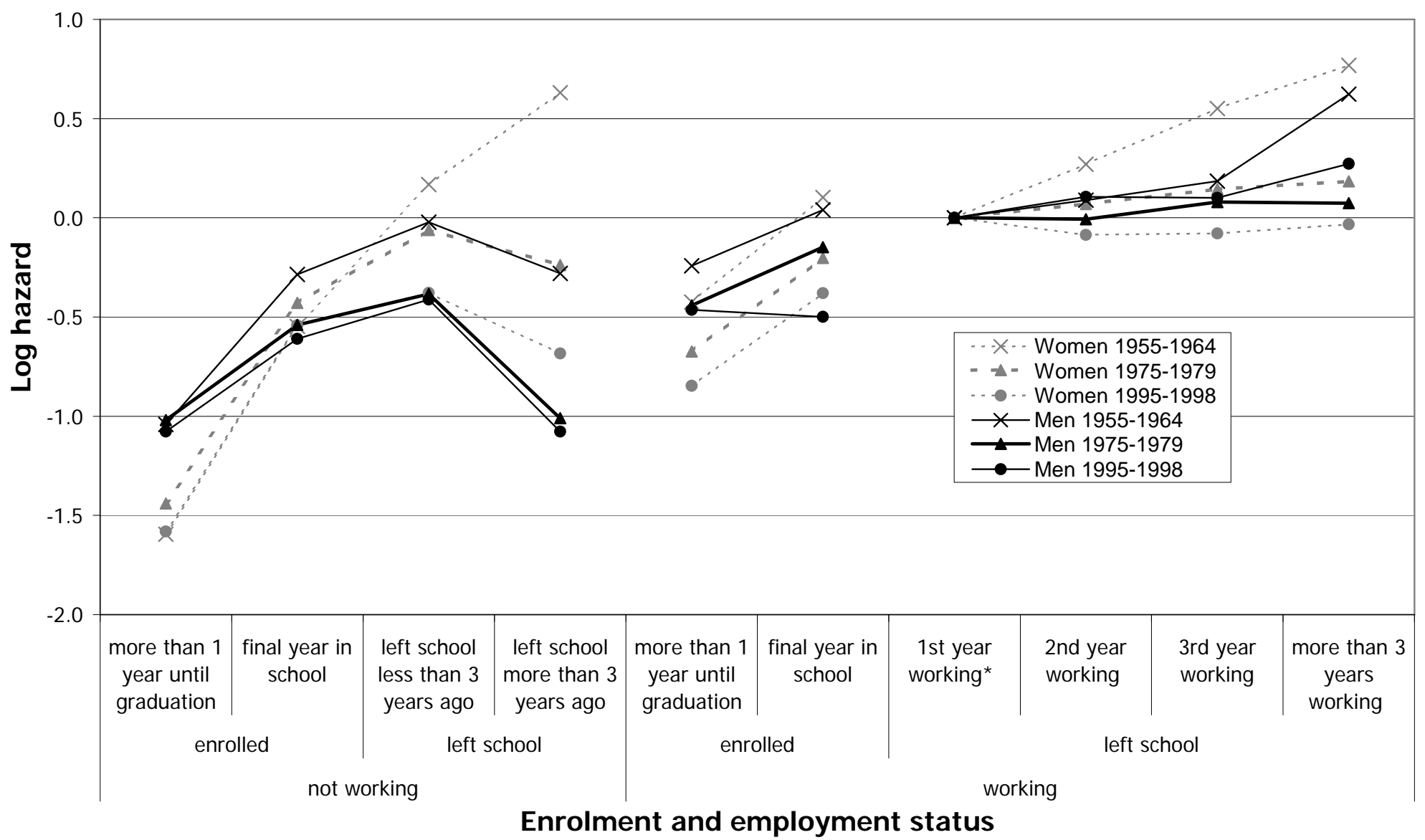




\section{Figure 4}

Estimated effects of level of education attained on entry into first parenthood for selected years (without main period effect). The asterisk denotes the baseline category.

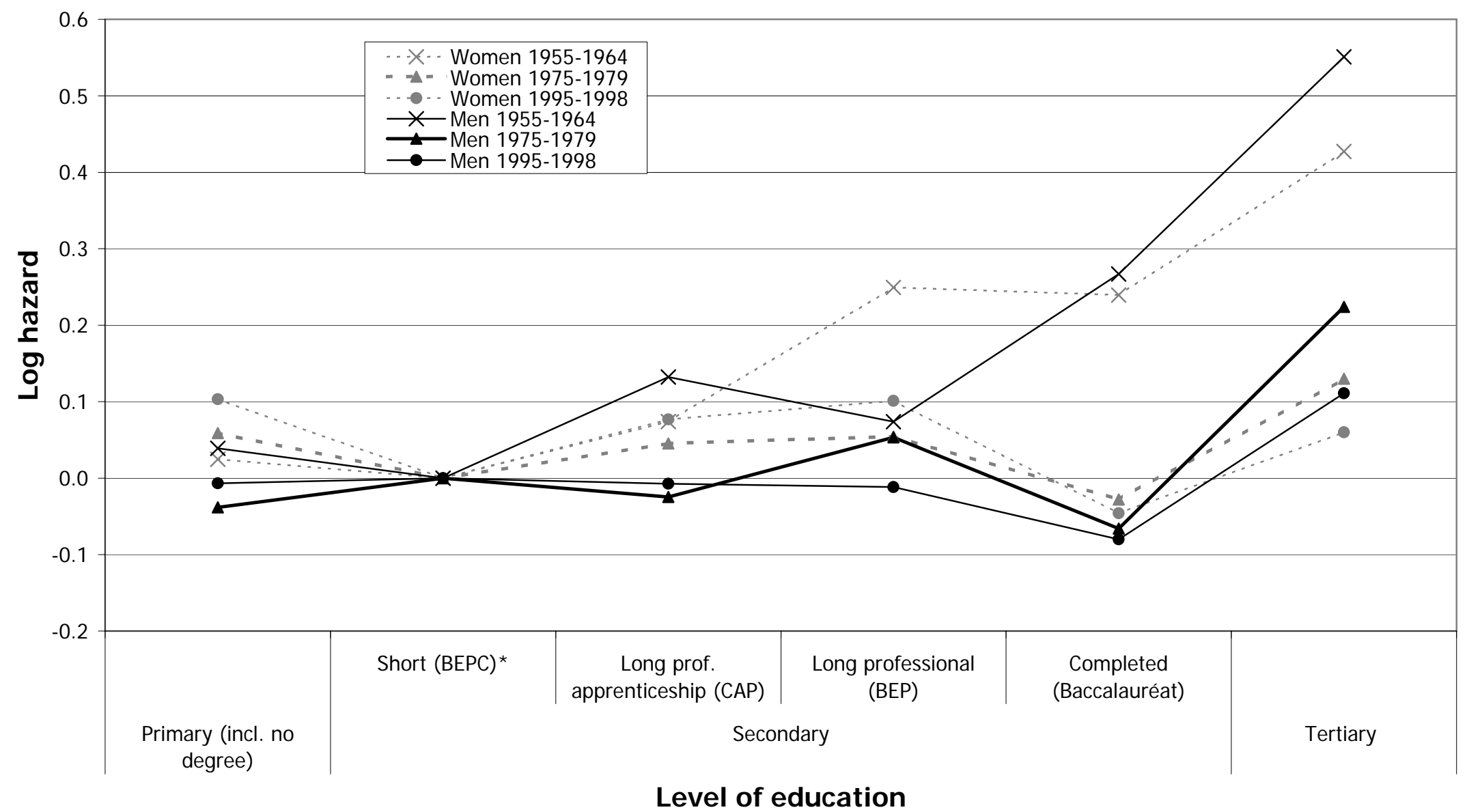




\section{Figure 5}

Estimated effects of interaction between enrolment and employment status on entry into parenthood for selected years (without main period effect). The asterisk denotes the baseline level.

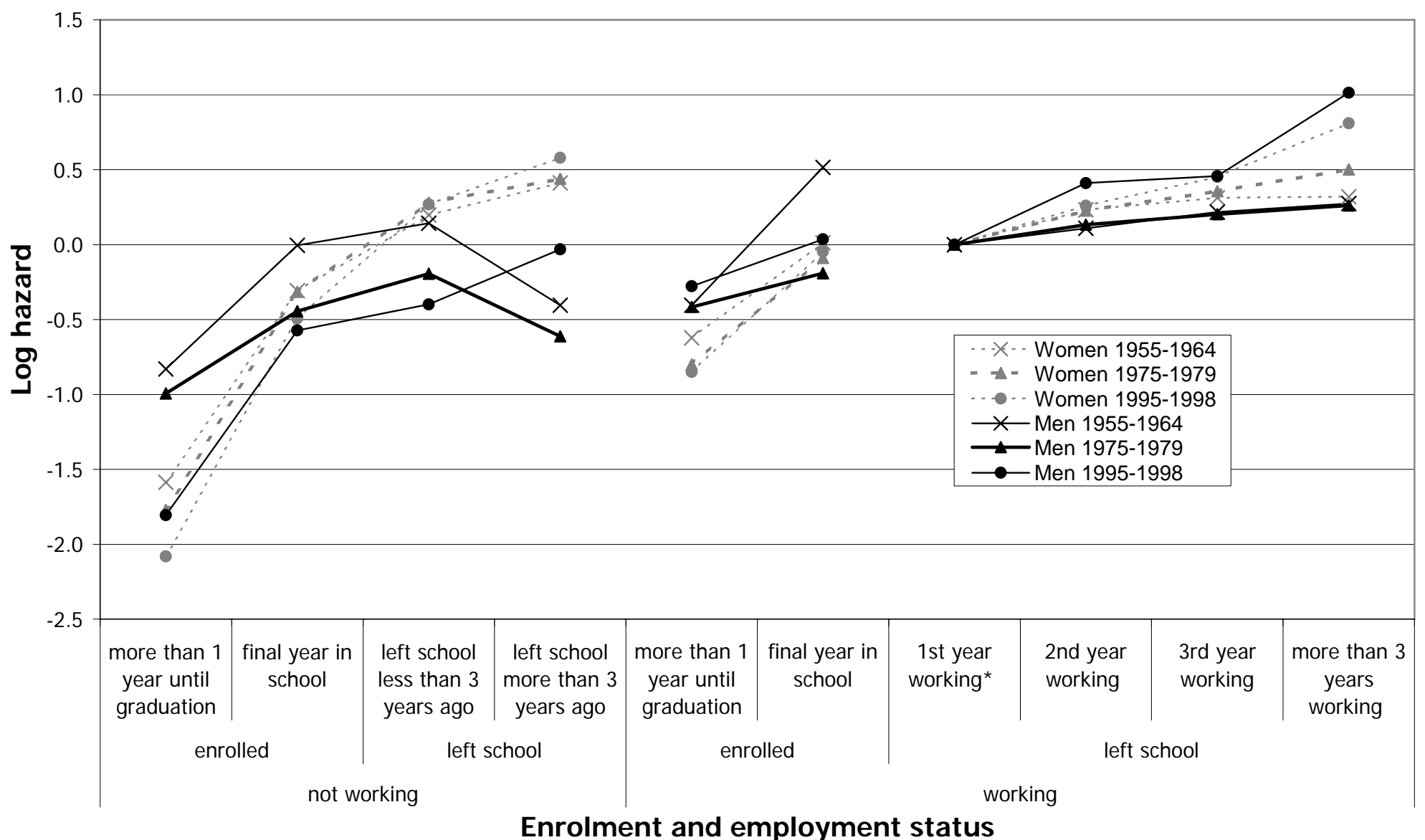




\section{VIENNA INSTITUTE OF DEMOGRAPHY}

\section{Working Papers}

Prskawetz, Alexia, Marija Mamolo, and Henriette Engelhardt, Reconsidering the Relation between Fertility and Key Fertility-Related Demographic Behaviour across Space and Time, VID Working Paper 09/2006.

Mamolo, Marija, Union Formation, Marriage and First Birth: Convergence Across Cohorts in Austria, Hungary, Northern Italy and Slovenia? VID Working Paper 08/2006.

Goujon, Anne and Samir K.C., Past and Future of Human Capital in Southeast Asia: From 1970 to 2030, VID Working Paper 07/2006.

Lyngstad, Torkild H., Does Community Context have Important Bearings on the Divorce Rate? VID Working Paper 06/2006.

Winkler-Dworak, Maria, The Low Mortality of a Learned Society, VID Working Paper 05/2006.

Kim, Jungho and Alexia Prskawetz, External Shocks, Household Consumption and Fertility in Indonesia, VID Working Paper 04/2006.

Schwarz, Franz, Behavioral Explanation for Educational Health and Mortality Differentials in Austria, VID Working Paper 03/2006.

Schwarz, Franz, The Contributions of Diseases to Increasing Educational Mortality Differential in Austria, VID Working Paper 02/2006.

Goujon, Anne, Vegard Skirbekk, Katrin Fliegenschnee and Pawel Strzelecki, New Times, Old Beliefs: Projecting the Future Size of Religions in Austria, VID Working Paper 01/2006.

Ediev, Dalkhat M., Extension of Fisher's Classical Result on Exponential Dynamics of the Reproductive Value to a Wide Class of Populations, VID Working Paper $10 / 2005$.

Ediev, Dalkhat M., Long-Term Effects of Childbearing Postponement, VID Working Paper 09/2005.

Philipov, Dimiter, Zsolt Spéder, and Francesco C. Billari, Now or Later? Fertility Intentions in Bulgaria and Hungary and the Impact of Anomie and Social Capital, VID Working Paper 08/2005.

The Vienna Institute of Demography Working Paper Series receives only limited review. Views or opinions expressed herein are entirely those of the authors. 